\title{
Synthesis and antibacterial activity of novel lincomycin derivatives. IV. Optimization of an $\mathrm{N}-6$ substituent
}

\author{
Ko Kumura, Yoshinari Wakiyama, Kazutaka Ueda, Eijiro Umemura, Yoko Hirai, Keiko Yamada and \\ Keiichi Ajito
}

The design and synthesis of lincomycin derivatives modified at the C- 6 and C-7 positions are described. A substituent at the C-7 position is a 5-aryl-1,3,4-thiadiazol-2-yl-thio group that generates antibacterial activities against macrolide-resistant Streptococcus pneumoniae and Streptococcus pyogenes carrying an erm gene. An additional modification at the C-6 position was explored in application of information regarding pirlimycin and other related compounds. These dual modifications were accomplished by using methyl $\alpha$-thiolincosaminide as a starting material. As a result of these dual modifications, the antibacterial activities were improved compared with those of compounds with a single modification at the C-7 position. The antibacterial activities of selected compounds in this report against macrolide-resistant $S$. pneumoniae and $S$. pyogenes with an erm gene were superior to those of telithromycin.

The Journal of Antibiotics (2017) 70, 1112-1121; doi:10.1038/ja.2017.143; published online 8 November 2017

\section{INTRODUCTION}

Macrolide antibiotics have had a significant role in treatment of respiratory infections. Clarithromycin ${ }^{1}$ and azithromycin ${ }^{2}$ synthesized from 14-membered erythromycin are clinically important macrolides and widely used over many years (Figure 1). However, prevalence of macrolide resistance in Gram-positive bacteria such as S. pneumoniae has been causing serious clinical problems. ${ }^{3,4}$ Clarithromycin and azithromycin are inactive against resistant strains of $S$. pneumoniae, which have a mechanism of ribosome methylation by an erm gene and decreased antibacterial activities against resistant strains with a mef gene, which expresses the efflux pump. Although telithromycin (TEL) ${ }^{5}$ derived from natural erythromycin has improved antibacterial activities against resistant $S$. pneumoniae with an erm gene and/or a mef gene, safety problems ${ }^{6}$ of TEL made its clinical use difficult. Another promising example is a group of 16-membered azalides ${ }^{7,8}$ that are effective against resistant $S$. pneumoniae with an erm gene. However, these compounds are still in the research phase and have not entered development. Novel therapeutic agents that are effective against the resistant S. pneumoniae without concerns of adverse events are required in clinical sites.

Lincomycin (LCM) ${ }^{9}$ (Figure 2) is one of secondary metabolites of Streptomyces lincolnensis and has been used as antibacterial agent mainly against Gram-positive bacteria. Chemical modification of LCM led to clindamycin (CLDM) ${ }^{10}$ which has an enhanced antibacterial activity against $S$. pneumoniae and an improved pharmacokinetic profile. Although LCM and CLDM are distinct from macrolide antibiotics in their chemical structures, they have cross-resistance against $S$. pneumoniae with an erm gene. ${ }^{11}$ The cross-resistance is consistent with the result of X-ray crystallographic studies that revealed the overlap of binding site on 50 S ribosome. Thus, CLDM shows almost no antibacterial activity against these resistant pathogens as shown in Table 1. CLDM, however, is attractive because of its safety profile and effectiveness against resistant pathogens expressing a drug efflux pump. In addition, CLDM has no gastrointestinal side effect caused by modulating motilin receptor. ${ }^{12}$ Furthermore, CLDM has been reported to be effective for invasive group A streptococcal infections caused by $S$. pyogenes. ${ }^{13}$ A simple chemical structure of CLDM compared with that of macrolide is attractive from the viewpoint of production cost. Based on these reasons, we have been expanding chemical modifications of lincosamide, in order to generate a novel antibacterial agent that is effective against resistant S. pneumoniae and S. pyogenes with erm and mef genes.

It has been reported that modifications at the C-7 position of LCM tend to provide comparable antibacterial activity to that of LCM. ${ }^{14,15}$ against susceptible strains. We reported chemical modifications of LCM and clarified that (7S)-7-deoxy-7-thiolincomycin derivatives ${ }^{16-22}$ exhibited moderate to strong antibacterial activities against $S$. pneumoniae and S. pyogenes with an erm gene. Compound 1 that has a phenyl-thiadiazol-2-yl-thio moiety to the C-7 position showed response (very weak antibacterial activities) against those resistant pathogens (Table 1). A nitro group at the 2-position and methoxy groups at the 4- and 5-positions in the benzene ring of $\mathbf{1}$ had a key role for enhancement of the antibacterial activity against $S$. pneumoniae with an erm gene. ${ }^{21,22}$

The ring-size modification of a proline moiety linked to the N-6 position of lincosamides was reported by several group ${ }^{23-27}$. As for the piperidine derivatives, pirlimycin ${ }^{23}$ has been used for animal drugs and VIC-105555 $5^{24-26}$ displays enhanced in vitro and in vivo activities

Pharmaceutical Research Center, Meiji Seika Pharma Co., Ltd, Yokohama, Japan

Correspondence: Dr K Ajito, Pharmaceutical Research Center, Meiji Seika Pharma Co., Ltd, 760 Morooka-cho, Kohoku-ku, Yokohama 222-8567, Japan.

E-mail: keiichi.ajito@meiji.com

Received 22 August 2017; revised 7 October 2017; accepted 7 October 2017; published online 8 November 2017 


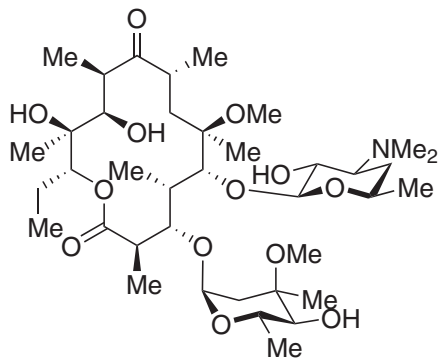

Clarithromycin (CAM)

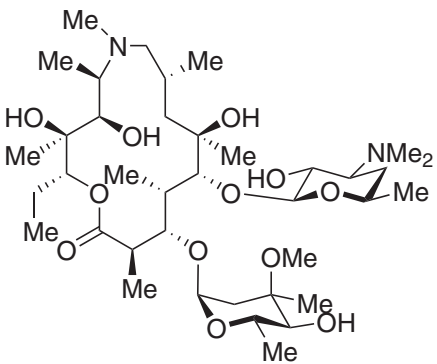

Azithromycin (AZM)

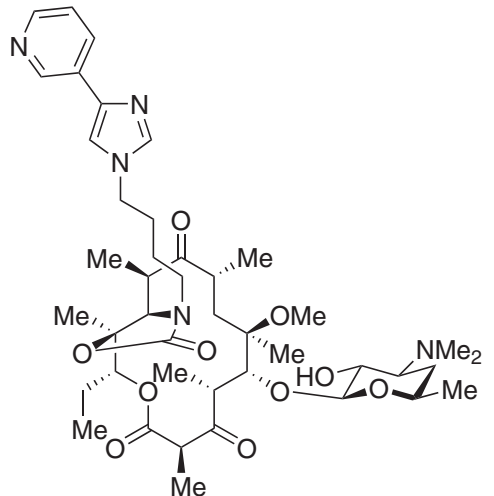

Telithromycin (TEL)

Figure 1 Structures of widely used macrolides, clarithromycin and azithromycin, and telithromycin.

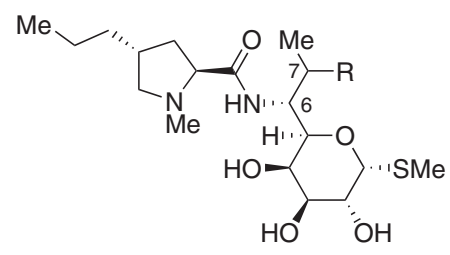

Lincomycin (LCM): $\mathrm{R}=-\mathrm{OH}$

Clindamycin (CLDM): $\mathrm{R}=\cdots \cdot \mathrm{Cl}$

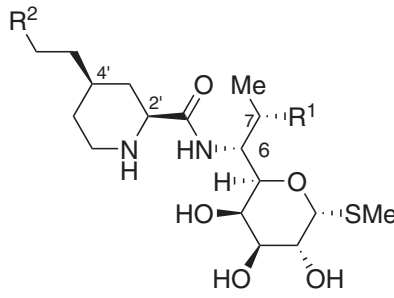

Pirlimycin: $\mathrm{R}^{1}=\mathrm{Cl} ; \mathrm{R}^{2}=\mathrm{H}$

VIC-105555: $R^{1}=R^{2}=M e$

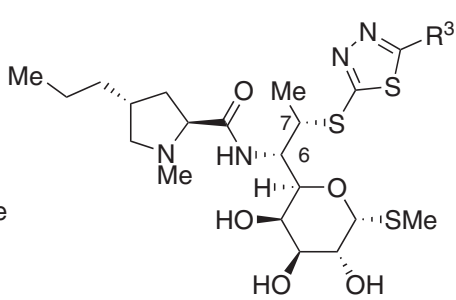

1: $\mathrm{R}^{3}=$

2: $\mathrm{R}^{3}$<smiles>[O]</smiles>

3: $\mathrm{R}^{3}$<smiles>COc1cc(OC)c([N+](=O)[O-])cc1I</smiles>

Figure 2 Structures of lincomycin, clindamycin, pirlimycin, VIC-105555, compounds 1, 2 and $\mathbf{3}$.

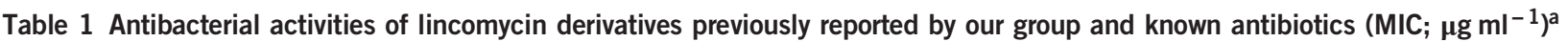

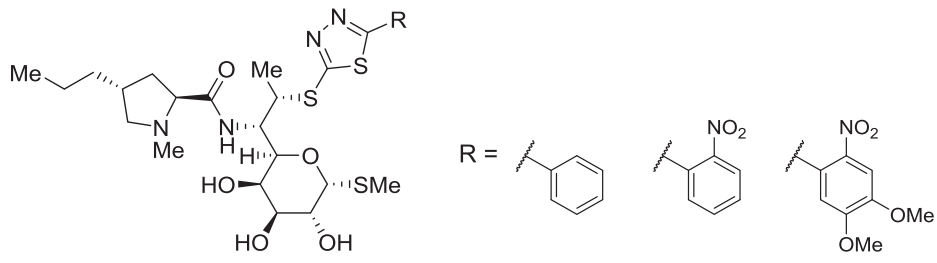

\begin{tabular}{|c|c|c|c|c|c|c|c|}
\hline No. Test organism ${ }^{b}$ & Characteristics & 1 & 2 & 3 & $C L D M$ & $C A M$ & $T E L$ \\
\hline 1 S. pneumoniae DP1 TypeI & susceptible & 0.13 & 0.06 & 0.015 & 0.13 & 0.03 & $\leq 0.008$ \\
\hline 2 S. pneumoniae \#2 & susceptible & 0.06 & 0.06 & 0.015 & 0.13 & 0.03 & $\leq 0.008$ \\
\hline 3 S. pneumoniae \#3 & susceptible & 0.06 & 0.13 & 0.015 & 0.13 & 0.015 & $\leq 0.008$ \\
\hline 4 S. pneumoniae \#4 & ermB methylase (c) & 64 & 4 & 0.5 & $>128$ & $>128$ & 0.5 \\
\hline 5 S. pneumoniae \#5 & ermB methylase (c) & 32 & 8 & 0.25 & $>128$ & $>128$ & 1 \\
\hline 6 S. pneumoniae \#6 & ermB methylase $(\mathrm{c})+$ mefE & 128 & 64 & 1 & $>128$ & $>128$ & 1 \\
\hline 7 S. pneumoniae \#7 & ermB methylase (i) & 16 & 4 & 0.25 & $>128$ & $>128$ & 0.06 \\
\hline 8 S. pneumoniae \#8 & ermB methylase (i) & 16 & 4 & 0.25 & $>128$ & $>128$ & 0.06 \\
\hline 9 S. pneumoniae \#9 & mefE efflux & 0.06 & 0.06 & $\leq 0.008$ & 0.13 & 0.5 & 0.06 \\
\hline 10 S. pneumoniae \#10 & mefE efflux & 0.06 & 0.06 & 0.015 & 0.13 & 0.5 & 0.06 \\
\hline 11 S.pyogenes Cook & susceptible & 0.06 & 0.06 & 0.03 & 0.13 & 0.015 & 0.015 \\
\hline 12 S. pyogenes \#2 & ermB methylase (c) & 4 & 4 & 0.25 & $>128$ & $>128$ & 16 \\
\hline 13 S. pyogenes \#3 & mefE efflux & 0.13 & 0.13 & 0.015 & 0.13 & 8 & 0.5 \\
\hline 14 H. influenzae \#1 & susceptible & 16 & 16 & 2 & 8 & 2 & 0.5 \\
\hline 15 H. influenzae \#2 & susceptible & 16 & 8 & 2 & 8 & 4 & 2 \\
\hline 16 H. influenzae \#3 & susceptible & 64 & 64 & 2 & 32 & 8 & 1 \\
\hline
\end{tabular}

Abbreviations: c, constitutive; i, inducible; CAM, clarithromycin; CLDM, clindamycin; TEL, telithromycin.

${ }^{a}$ All antibacterial evaluations were performed as hydrochloride. Gray shading strains are target strains.

${ }^{\mathrm{b}}$ All strains except standard organisms were clinically isolated. 


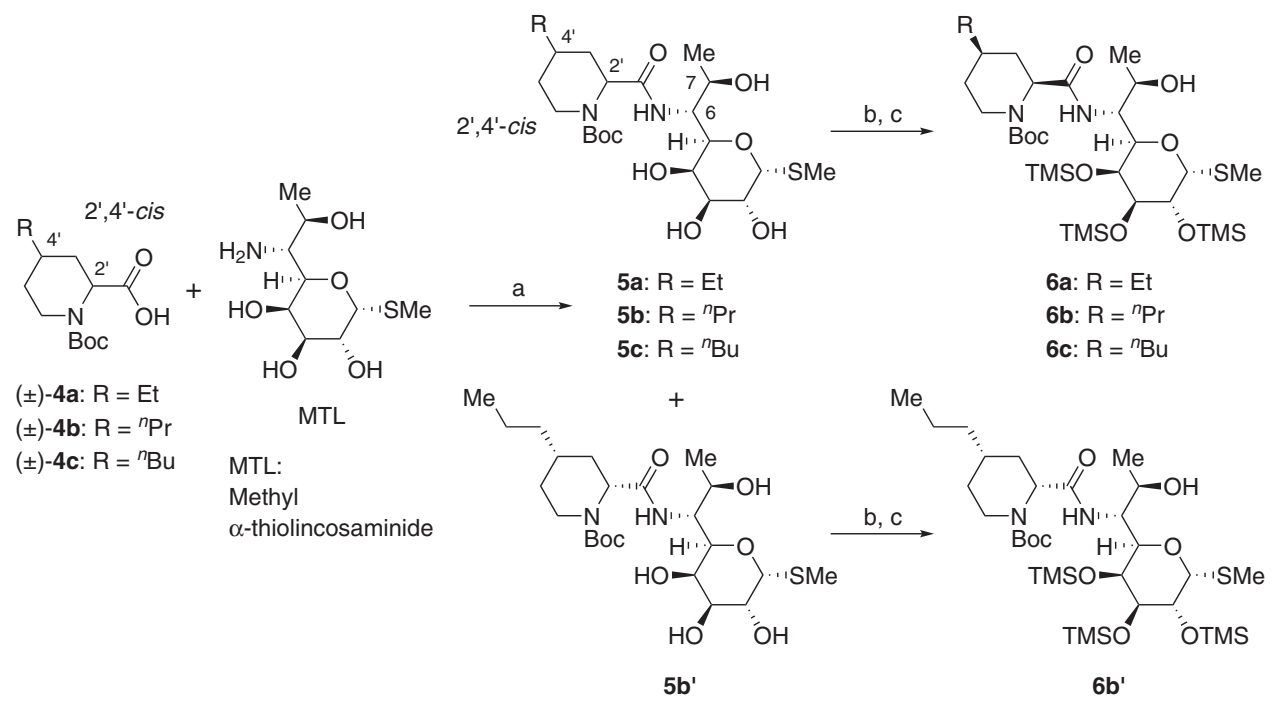

Scheme 1 Synthesis of key intermediates having a 4-substituted piperidine 2-carbonyl group. Conditions: (a) DCC, HOBt, DMF, rt; (b) TMSCl, HMDS, pyridine, rt; (c) $6 \mathrm{~N} \mathrm{AcOH}, \mathrm{MeOH}$, rt.

with superior efficacy over clindamycin in several experimental models (Figure 2). Although these compounds did not show antibacterial activities against resistant Gram-positive bacteria with an erm gene, in vitro and/or in vivo properties of (7S)-7-deoxy-7-thiolincomycin derivatives are expected to be improved by the modification of the proline moiety. In this article, we report optimization of the proline moiety of (7S)-7-deoxy-7-(5-(2-nitrophenyl)-1,3,4-thiadiazol-2-ylthio)lincomycin derivatives, in order to generate novel LCM derivatives exhibiting stronger antibacterial activities than TEL.

\section{Chemistry}

Synthesis of important intermediates that have $4^{\prime}$-substituted piperidine-2'-carbonyl group instead of a natural 4 '-propyl proline part is shown in Scheme 1. A racemic mixture of 2,4-cis-piperidinecarboxylic acids was prepared by a reported procedure ${ }^{28}$ from 4 -alkylpyridine. The protection of an amine gave carboxylic acids $( \pm)-\mathbf{4 a},( \pm)-\mathbf{4 b}$ and $( \pm)-\mathbf{4 c}$. Condensation of these carboxylic acids with methyl $\alpha$-thiolincosaminide ${ }^{29}$ gave $1^{\prime}-N$-Boc protected compounds $\mathbf{5 a}, \mathbf{5 b}$ and $\mathbf{5 c}$ as a 1:1 diastereomeric mixture. These mixtures showed two spots on TLC, but complete separation by silica gel chromatography was difficult. After exploring a solvent for selective precipitation, we found that less polar isomer was precipitated from ethyl acetate and more polar isomer was enriched in mother liquor. Birkenmeyer et al. ${ }^{23}$ reported that more active $2^{\prime}-\beta-4^{\prime}-\beta$-cis isomers of pirlimycin derivatives showed more polar profile on TLC. Based on the report, the more polar isomer of $\mathbf{5 b}$ was assigned as a $2^{\prime}-\beta-4^{\prime}-\beta-c i s$ isomer. The $2^{\prime}-\beta-4^{\prime}-\beta$-cis isomers of $\mathbf{5 b}$ were converted to tetra-Otrimethylsilyl intermediate, which was followed by regioselective deprotection of the 7-O-trimethylsilyl group and silica gel column chromatography, afforded $\mathbf{6 b}$. The other $2^{\prime}-\alpha-4^{\prime}-\alpha-c i s$ isomer $\mathbf{6} \mathbf{b}^{\prime}$ was prepared from less polar isomer $\left(\mathbf{5} \mathbf{b}^{\prime}\right)$ as well. Regarding $4^{\prime}$-ethyl and $4^{\prime}$ - $n$-butyl derivatives, $2^{\prime}-\beta-4^{\prime}-\beta$-cis isomers $\mathbf{6 a}$ and $\mathbf{6 c}$ were obtained in the similar manner to $\mathbf{6} \mathbf{b}$.

Synthesis of (7S)-7-deoxy-7-(5-phenyl-1,3,4-thiadiazol-2-yl-thio)LCM derivatives modified at the C-6 position is shown in Scheme 2. Introductions of the 5-substituted 1,3,4-thiadiazol-2-yl-thio group at the $\mathrm{C}-7$ position were achieved by Mitsunobu reaction and subsequent deprotection led to target compounds $7 \mathbf{a}-7 \mathbf{k}$. In order to obtain information on the relationship between stereochemistry in the piperidine moiety and antibacterial activity, $2^{\prime}-\alpha-4^{\prime}-\alpha-c i s$ isomer $7 \mathbf{b}^{\prime}$ was also synthesized in the similar manner to $7 \mathbf{a}-7 \mathbf{k}$ from $\mathbf{6} \mathbf{b}^{\prime}$. Compound $\mathbf{7 b}$ was more polar than $\mathbf{7} \mathbf{b}^{\prime}$ on TLC as in the case of $\mathbf{6 b}$ and $\mathbf{6} \mathbf{b}^{\prime}$. A major reason for relatively low yield of these Mitsunobu reactions was explained by generation of an $\mathrm{N}$-connected byproduct in the thiadiazole moiety instead of the desired $S$-connected derivative. $1^{\prime}$-Methylated compounds $\mathbf{8 d}, \mathbf{8 e}$ and $\mathbf{8 f}$ were prepared by reductive $\mathrm{N}$-methylation of the corresponding secondary amine. Synthesis of VIC-105555 and $\mathbf{1 0}$ were conducted based on the reported procedure $^{24}$ as shown in Scheme 3. The reduction of 9 gave a diastereomeric mixture of VIC-105555 and 10. We separated these isomers and a more polar isomer was assigned as VIC-105555.

\section{RESULTS AND DISCUSSION}

Antibacterial activities of LCM derivatives that have the 5-(2-nitrophenyl)-1,3,4-thiadiazol-2-yl-thio group at the C-7 position and the $4^{\prime}$-alkyl piperidin-2'-carbonylamino group at the C-6 position are shown in Table 2. Regarding stereoisomers $\mathbf{7 b}$ and $\mathbf{7} \mathbf{b}^{\prime}$, which are $4^{\prime}$-propyl derivatives, antibacterial activities of $\mathbf{7 b}$ were clearly more potent than those of $\mathbf{7} \mathbf{b}^{\prime}$ as expected. According to the result, the assignment of stereochemistry in the piperidine moiety was also supported by antibacterial activity. Similarly, VIC-105555 showed reported antibacterial activities against $S$. pneumoniae and $S$. pyogenes without an erm gene and antibacterial activities of stereoisomer 10 was much weaker than those of VIC-105555. Compared with a natural proline analog 2 , transformation to $4{ }^{\prime}-n$-propylpiperidine- 2 '-carbonyl analog remarkably improved the antibacterial activities against resistant S. pneumoniae and S. pyogenes with an erm gene. $4^{\prime}$-Ethyl analog (7a) showed improved antibacterial activities against susceptible strains of $S$. pneumoniae and S. pyogenes compared to 2. However, its antibacterial activities against resistant $S$. pneumoniae with an erm gene were weaker than those of $\mathbf{7 b}$. In contrast, $4^{\prime}-n$-butyl analog $(\mathbf{7 c})$ exhibited more potent antibacterial activities than $\mathbf{7 b}$ against all of the test organisms. Antibacterial activities of these derivatives were significantly superior to TEL against $S$. pyogenes with an erm gene.

Table 3 shows antibacterial activities of 4-fluoro-2-nitrophenyl analogs. The antibacterial activities of $\mathbf{7 d}, 7 \mathrm{e}$ and $\mathbf{7 f}$ indicated that the effect of a fluorine atom on antibacterial activity against $S$. pneumoniae and S. pyogenes was unclear. However, antibacterial 


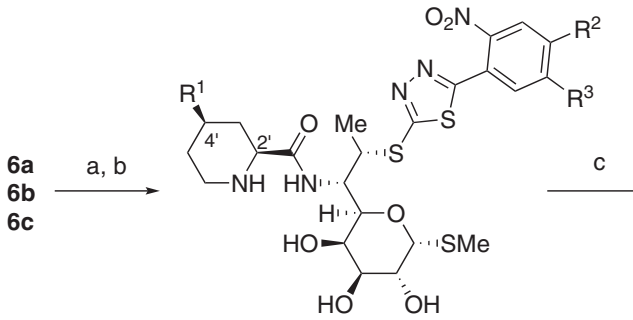

7a: $R^{1}=E t, R^{2}=R^{3}=H$

7b: $\mathrm{R}^{1}={ }^{n} \mathrm{Pr}, \mathrm{R}^{2}=\mathrm{R}^{3}=\mathrm{H}$

7g: $\mathrm{R}^{1}={ }^{n} \mathrm{Pr}, \mathrm{R}^{2}=\mathrm{H}, \mathrm{R}^{3}=\mathrm{NHMe}$

7c: $R^{1}={ }^{n} \mathrm{Bu}, \mathrm{R}^{2}=\mathrm{R}^{3}=\mathrm{H}$

7d: $R^{1}=E t, R^{2}=F, R^{3}=H$

7e: $\mathrm{R}^{1}={ }^{n} \mathrm{Pr}, \mathrm{R}^{2}=\mathrm{F}, \mathrm{R}^{3}=\mathrm{H}$

7f: $R^{1}={ }^{n} \mathrm{Bu}, \mathrm{R}^{2}=\mathrm{F}, \mathrm{R}^{3}=\mathrm{H}$

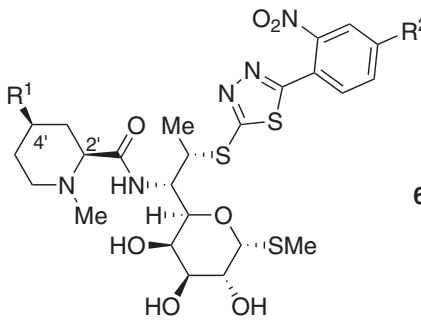

8d: $R^{1}=E t, R^{2}=F$

8e: $R^{1}={ }^{n} \operatorname{Pr}, R^{2}=F$

8f: $R^{1}={ }^{n} \mathrm{Bu}, \mathrm{R}^{2}=\mathrm{F}$

Scheme 2 Synthesis of (7S)-7-deoxy-7-(5-phenyl-1,3,4-thiadiazol-2-yl-thio)-LCM derivatives having a 4-substituted piperidine 2-carbonyl group. Conditions: (a) $\mathrm{ArSH}, \mathrm{DEAD}, \mathrm{PPh}_{3}, \mathrm{THF}$ or toluene, $0^{\circ} \mathrm{C}$ to rt; (b) TFA, DCM, $-20^{\circ} \mathrm{C}$ to rt; (c) $36 \% \mathrm{HCHO}, \mathrm{NaBH}(\mathrm{OAc})_{3}, \mathrm{AcOH}$, $\mathrm{MeOH}$ or EtOH, rt.

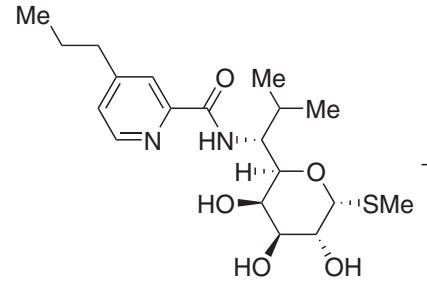

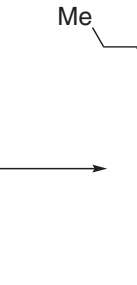

VIC-105555

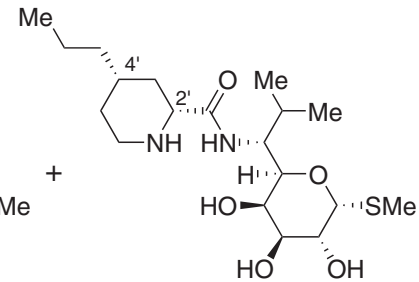

10

Scheme 3 Synthesis of VIC-105555 and its 2'- $\alpha-4^{\prime}-\alpha-c i s$ isomer 10. Condition: $\mathrm{H}_{2}, \mathrm{PtO}_{2}$, conc. $\mathrm{HCl}, \mathrm{MeOH}-\mathrm{H}_{2} \mathrm{O}$, rt.

Table 2 Antibacterial activities of novel lincomycin derivatives (MIC; $\left.\mu \mathrm{g} \mathrm{ml}^{-1}\right)^{\mathrm{a}}$

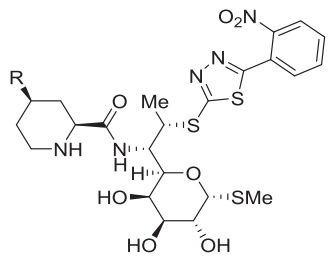

$\mathrm{R}=\quad$ Et $\quad{ }^{n} \mathrm{Pr} \quad{ }^{n} \mathrm{Bu}$

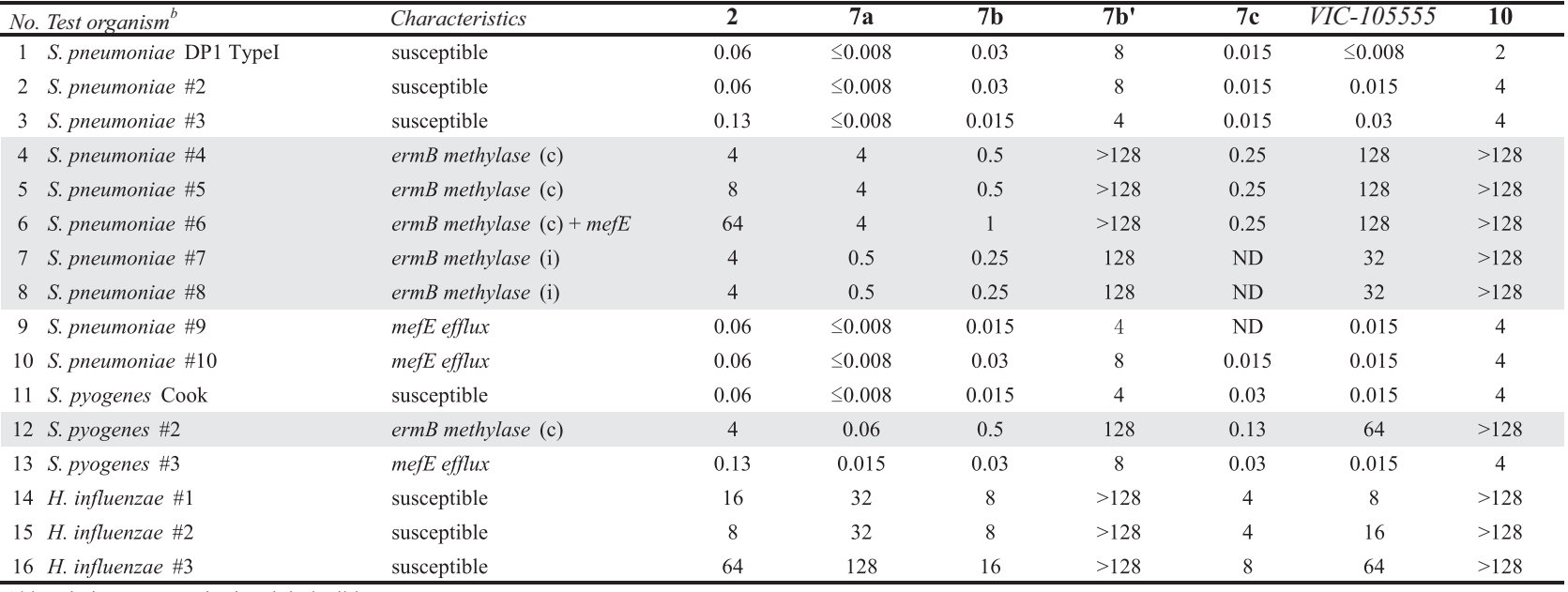

Abbreviations: c, constitutive; i, inducible.

${ }^{a}$ All antibacterial evaluations were performed as hydrochloride. Gray shading strains are target strains.

${ }^{\mathrm{b}}$ All strains except standard organisms were clinically isolated. 
Table 3 Antibacterial activities of novel lincomycin derivatives (MIC; $\left.\mu \mathrm{g} \mathrm{ml}^{-1}\right)^{\mathrm{a}}$

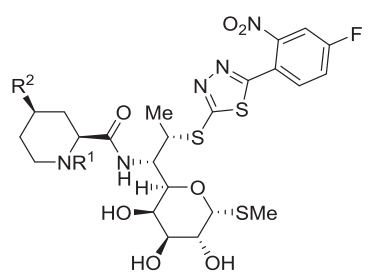

$$
\begin{array}{lllllll}
\mathrm{R}^{1}= & \mathrm{H} & \mathrm{Me} & \mathrm{H} & \mathrm{Me} & \mathrm{H} & \mathrm{Me} \\
\mathrm{R}^{2}= & \text { Et } & \text { Et } & { }^{n} \mathrm{Pr} & { }^{n} \mathrm{Pr} & { }^{n} \mathrm{Bu} & { }^{n} \mathrm{Bu}
\end{array}
$$

\begin{tabular}{|c|c|c|c|c|c|c|c|c|}
\hline No. Test organism ${ }^{b}$ & Characteristics & $7 d$ & 8d & $7 e$ & $8 \mathbf{8 e}$ & $7 f$ & $8 f$ & $T E L$ \\
\hline 1 S. pneumoniae DP1 TypeI & susceptible & $\leq 0.008$ & 0.015 & 0.03 & 0.06 & 0.015 & 0.03 & $\leq 0.008$ \\
\hline 2 S. pneumoniae \#2 & susceptible & $\leq 0.008$ & $\leq 0.008$ & 0.03 & 0.06 & 0.015 & 0.03 & $\leq 0.008$ \\
\hline 3 S. pneumoniae \#3 & susceptible & $\leq 0.008$ & $\leq 0.008$ & 0.03 & 0.06 & 0.03 & 0.06 & $\leq 0.008$ \\
\hline 4 S. pneumoniae \#4 & ermB methylase (c) & 1 & $>128$ & 0.5 & 4 & 0.13 & 1 & 0.5 \\
\hline 5 S. pneumoniae \#5 & ermB methylase (c) & 2 & 64 & 1 & 4 & 0.25 & 1 & 1 \\
\hline 6 S. pneumoniae \#6 & ermB methylase $(\mathrm{c})+$ mefE & 4 & $>128$ & 1 & 4 & 0.25 & 2 & 1 \\
\hline 7 S. pneumoniae \#7 & ermB methylase (i) & 1 & 8 & 0.25 & ND & 0.06 & 0.25 & 0.06 \\
\hline 8 S. pneumoniae \#8 & ermB methylase (i) & 1 & 4 & 0.25 & ND & 0.06 & 0.25 & 0.06 \\
\hline 9 S. pneumoniae \#9 & mefE efflux & $\leq 0.008$ & 0.015 & $\leq 0.008$ & ND & $\leq 0.008$ & 0.03 & 0.06 \\
\hline 10 S. pneumoniae \#10 & mefE efflux & $\leq 0.008$ & 0.015 & 0.015 & 0.06 & 0.015 & 0.03 & 0.06 \\
\hline 11 S. pyogenes Cook & susceptible & $\leq 0.008$ & 0.015 & 0.03 & 0.13 & 0.015 & 0.03 & 0.015 \\
\hline 12 S. pyogenes \#2 & ermB methylase (c) & 0.25 & 1 & 0.5 & 2 & 0.13 & 0.5 & 16 \\
\hline 13 S. pyogenes \#3 & mefE efflux & 0.015 & 0.03 & 0.03 & 0.13 & 0.03 & 0.03 & 0.5 \\
\hline 14 H. influenzae \#1 & susceptible & 8 & 64 & 4 & 16 & 2 & 4 & 0.5 \\
\hline 15 H. influenzae \#2 & susceptible & 8 & 32 & 2 & 8 & 1 & 2 & 2 \\
\hline 16 H. influenzae \#3 & susceptible & 32 & 128 & 4 & 16 & 2 & 4 & 1 \\
\hline
\end{tabular}

Abbreviations: c, constitutive; i, inducible; TEL, telithromycin.

${ }^{a}$ All antibacterial evaluations were performed as hydrochloride. Gray shading strains are target strains.

${ }^{\mathrm{b}}$ All strains except standard organisms were clinically isolated.

activities of $\mathbf{7 f}$ against $S$. pneumoniae with an erm gene were generally more potent than those of TEL as well as $7 \mathrm{c}$. On the other hand, $7 \mathbf{d}$, 7e and $7 \mathbf{f}$ exhibited enhanced antibacterial activities against Haemophilus influenzae compared with the corresponding compounds $7 \mathbf{a}, 7 \mathbf{b}$ and $7 \mathrm{c}$ without a fluorine atom. Compounds $\mathbf{8 d}, \mathbf{8 e}$ and $\mathbf{8 f}$, which have a methyl group at the 1 -position showed weaker antibacterial activities against resistant $S$. pneumoniae and $S$. pyogenes with an erm gene than corresponding 1'-demethyl compounds, respectively.

Antibacterial activities of 2-nitrophenyl derivatives that have substituent(s) in the benzene ring are shown in Table 4 . We previously reported ${ }^{22}$ that the introduction of a substituent such as a methylamino group and a methoxy group to the 5-position of the benzene ring of LCM analog possessing a natural 4'-propyproline moiety dramatically improved the antibacterial activities and their antibacterial activities were further enhanced by additional substitution at the 4-position of the benzene ring. According to the antibacterial activities of $7 \mathrm{~g}$ and $\mathbf{7 h}$, ring size expansion from a pyrrolidine ring found in the original LCM to the piperidine ring enhanced antibacterial activities against $S$. pneumoniae and $S$. pyogenes as in the case of the 2-nitrophenyl derivatives and 4-fluoro-2-nitrophenyl derivatives. In addition, the conversion of 4,5-dimethoxy-2-nitrophenyl derivative 3 (Figure 2) to a piperidine analog gave $7 \mathbf{j}$ that exhibited apparently more potent antibacterial activities against resistant $S$. pneumoniae and $S$. pyogenes with an erm gene than TEL. Although antibacterial activities of $4^{\prime}$-ethyl derivative (7i) against resistant $S$. pneumoniae with an erm gene were remarkably weakened, $4^{\prime}$-n-butyl derivative (7k) showed more potent antibacterial activities against resistant $S$. pneumoniae and $S$. pyogenes with an erm gene than TEL. It should be noted that antibacterial activities of $\mathbf{7 k}$ against resistant strains with an erm gene are almost same as those against susceptible strains. These results encouraged us to investigate the antibacterial activities of Mycoplasma pneumoniae. It is reported that macrolide resistant M. pneumoniae has been prevailing in China, Japan and other countries. ${ }^{30}$ Compounds tested showed potent antibacterial activities against resistant M. pneumonia, except for 7 h (\#18).

In summary, we previously reported that 1 possessing the 5-phenyl1,3,4-thiadiazol-2-yl-thio group at the C-7 position showed weak antibacterial activities against the resistant pathogens. In the course of our continuous chemical derivatization, target antibacterial activities were significantly improved. Compound 3 that has two methoxy groups at the benzene ring exhibited potency comparable to that of TEL. In this article, an additional modification at the C-6 position led to $7 \mathbf{k}$ possessing the 4- $n$-butylpiperidine-2-carbonyl group instead of the 4-n-propylpyrrolidin-2-carbonyl group at the C-6 position. Selected compound $\mathbf{7 k}$ exhibited significantly potent antibacterial activities against the resistant pathogens than TEL. This series of compounds has a nitro group at the benzene ring. Although it is known that a nitro group has a risk for mutagens and carcinogens, there are drugs and drug candidates that have a nitro group.

\section{CONCLUSIONS}

A series of LCM derivatives that have the 5-(2-nitrophenyl)-1,3,4thiadiazol-2-yl-thio moiety at the C-7 position in S-configuration and the 4-alkylpipelidine-2-carbonylamino group at the C-6 position was synthesized. Introductions of a substituent at the C-7 position were accomplished by the Mitsunobu reaction, and stereochemistry of 
Table 4 Antibacterial activities of novel lincomycin derivatives (MIC; $\left.\mu \mathrm{g} \mathrm{ml}^{-1}\right)^{\mathrm{a}}$
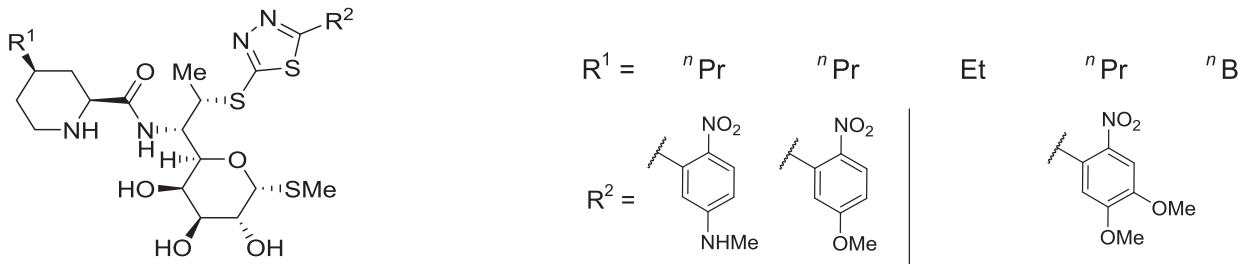

\begin{tabular}{|c|c|c|c|c|c|c|c|}
\hline No. Test organism ${ }^{b}$ & Characteristics & $7 g$ & $7 \mathbf{h}$ & $7 \mathbf{i}$ & $7 \mathbf{j}$ & $7 \mathbf{k}$ & $T E L$ \\
\hline 1 S. pneumoniae DP1 TypeI & susceptible & 0.06 & 0.015 & 0.015 & 0.03 & 0.03 & $\leq 0.008$ \\
\hline 2 S. pneumoniae \#2 & susceptible & 0.13 & 0.015 & 0.015 & 0.015 & 0.015 & $\leq 0.008$ \\
\hline 3 S. pneumoniae \#3 & susceptible & 0.06 & 0.015 & 0.015 & 0.06 & 0.03 & $\leq 0.008$ \\
\hline 4 S. pneumoniae \#4 & ermB methylase (c) & 0.25 & 0.13 & 1 & 0.06 & 0.03 & 0.5 \\
\hline 5 S. pneumoniae \#5 & ermB methylase (c) & 0.5 & 0.25 & 1 & 0.06 & 0.03 & 1 \\
\hline 6 S. pneumoniae \#6 & ermB methylase (c) + mefE & 0.5 & 0.25 & 1 & 0.13 & 0.03 & 1 \\
\hline 7 S. pneumoniae \#7 & ermB methylase (i) & 0.5 & 0.06 & 0.25 & 0.03 & 0.015 & 0.06 \\
\hline 8 S. pneumoniae \#8 & ermB methylase (i) & 0.25 & 0.06 & 0.25 & 0.03 & 0.015 & 0.06 \\
\hline 9 S. pneumoniae \#9 & mefE efflux & 0.03 & $\leq 0.008$ & 0.015 & $\leq 0.008$ & 0.015 & 0.06 \\
\hline 10 S. pneumoniae \#10 & mefE efflux & 0.06 & $\leq 0.008$ & 0.015 & 0.015 & 0.015 & 0.06 \\
\hline 11 S.pyogenes Cook & susceptible & 0.13 & 0.03 & 0.015 & 0.03 & 0.03 & 0.015 \\
\hline 12 S. pyogenes \#2 & ermB methylase (c) & 0.5 & 0.13 & 0.13 & 0.13 & 0.06 & 16 \\
\hline 13 S. pyogenes \#3 & mefE efflux & 0.13 & 0.03 & 0.015 & 0.03 & 0.06 & 0.5 \\
\hline 14 H. influenzae \#1 & susceptible & 4 & 4 & 4 & 2 & 2 & 0.5 \\
\hline 15 H. influenzae \#2 & susceptible & 4 & 2 & 4 & 2 & 2 & 2 \\
\hline 16 H. influenzae \#3 & susceptible & 4 & 4 & 16 & 2 & 2 & 1 \\
\hline 17 M. pneumoniae \#1 & susceptible & 0.03 & 0.03 & 0.015 & $\leq 0.008$ & 0.015 & 0.001 \\
\hline 18 M. pneumoniae \#2 & A2063G & 0.13 & 1 & 0.13 & $\leq 0.06$ & $\leq 0.06$ & 32 \\
\hline
\end{tabular}

Abbreviations: c, constitutive; i, inducible; TEL, telithromycin.

${ }^{a}$ All antibacterial evaluations were performed as hydrochloride. Gray shading strains are target strains.

${ }^{\mathrm{b}}$ All strains except standard organisms were clinically isolated.

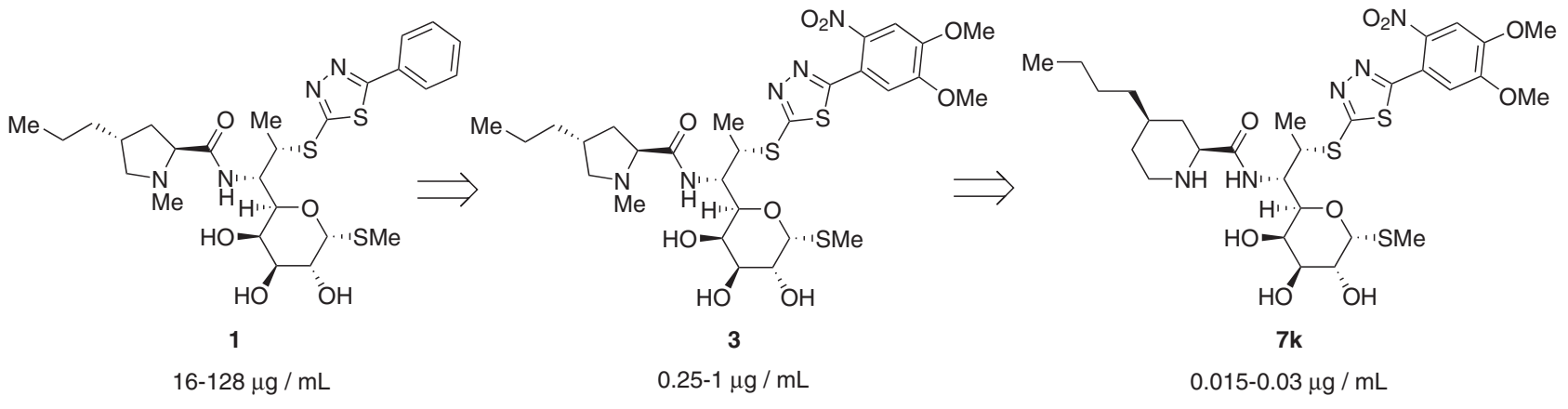

Figure 3 Summary of SAR between potency (MIC against resistant S. pneumoniae with an erm gene) and (7S)-5-aryl-1,3,4-thiadiazol-2-yl-thio-LCM derivatives.

4-alkylpiperidine-2-carbonyl moiety was assigned by the reported information on the relationship between stereochemistry and polarity. Additional modification at the C-6 position improved antibacterial activities of (7S)-1,3,4-thiadiazol-2-yl-thio LCM derivatives. In this study, we found the 4- $n$-butylpiperidine-2-carbonylamino group had the most potent functionality at the C-6 position against resistant $S$. pneumoniae and $S$. pyogenes with an erm gene. In particular, compound $7 \mathbf{k}$ exhibited the most potent antibacterial activities among all our (7S)-1,3,4-thiadiazol-2-yl-thio-LCM derivatives and apparently more potent in vitro than TEL against the resistant strains. Summary of SAR between antibacterial activity against resistant $S$. pneumoniae with an erm gene and (7S)-7-(5-aryl-1,3,4-thiadiazol-2-yl-thio)-LCM derivatives is shown in Figure 3. This series of LCM derivatives is promising to overcome maclolide-resistant $S$. pneumoniae and S. pyogenes with an erm gene.

\section{EXPERIMENTAL PROCEDURES}

General

${ }^{1} \mathrm{H}$ NMR spectra were measured with Varian Gemini-300 (Varian, Inc., Palo Alto, CA, USA) for $300 \mathrm{MHz}$, JEOL JNM-GSX 400 (JEOL Ltd, Tokyo, Japan) 
for $400 \mathrm{MHz}$ or BRUKER Ascend 400 NMR spectrometer (BRUKER Corporation, Coventry, UK) for $400 \mathrm{MHz}$ in $\mathrm{CDCl}_{3}$ or $\mathrm{CD}_{3} \mathrm{OD}$ with $0.03 \%$ tetramethylsilane as an internal standard. MS spectra were obtained on a JEOL JMS-FABmate spectrometer or JEOL JMS-700 mass spectrometer or Agilent Technologies 6530-Q-TOF LC/MS mass spectrometer (Agilent Technologies, Santa Clara, CA, USA). The optical rotations were recorded with Jasco P-2300 digital polarimeter (Jasco, Tokyo, Japan). Column chromatography was performed with silica gel $60 \mathrm{~N}$ (Kanto Chemical, Tokyo, Japan, spherical, neutral).

\begin{abstract}
Mixture 5a of methyl 6- $N$-[(2'S, $\left.4^{\prime} R\right)-1^{\prime}-N$-(tert-butoxycarbonyl)-4'ethylpiperidine- $2^{\prime}$-carbonyl]- $\alpha$-thiolincosaminide and methyl $6-\mathrm{N}$ $\left[\left(2^{\prime} R, 4^{\prime} S\right)-1^{\prime}-N\right.$-(tert-butoxycarbonyl)-4' -ethylpiperidine- $2^{\prime}-$ carbonyl]- $\boldsymbol{\alpha}$-thiolincosaminide

To a solution of $( \pm)-4 \mathrm{a}(6.66 \mathrm{~g}, 25.9 \mathrm{mmol})$ in $N, N^{\prime}$-dimethylformamide $(45 \mathrm{ml})$ were added 1-hydroxybenzotriazole $(3.50 \mathrm{~g}, 25.9 \mathrm{mmol}), \mathrm{N}, \mathrm{N}^{\prime}$-dicyclohexylcarbodiimide ( $6.05 \mathrm{~g}, 29.3 \mathrm{mmol})$, methyl $\alpha$-thiolincosaminide $(7.37 \mathrm{~g}$, $29.1 \mathrm{mmol})$ and triethylamine $(10.0 \mathrm{ml}, 71.7 \mathrm{mmol})$, and stirred at room temperature for overnight. To the mixture was added $\mathrm{H}_{2} \mathrm{O}$ and filtrated. Ethyl acetate was added to the filtrate and washed with saturated aqueous $\mathrm{NaHCO}_{3}$. The organic phase was dried over $\mathrm{Na}_{2} \mathrm{SO}_{4}$, filtrated and concentrated under reduced pressure. The resulting residue was purified by silica gel column chromatography (hexane/ethyl acetate $=50 / 50$ to ethyl acetate, then ethyl acetate to ethyl acetate/MeOH $=90 / 10)$ to afford methyl $6-N-\left[1^{\prime}-N\right.$ - (tertbutoxycarbonyl)-4'-ethylpiperidine-2'-carbonyl]- $\alpha$-thiolincosaminide (18.5 g, $84.9 \%,\left(2^{\prime} S, 4^{\prime} R\right)$ isomer: $\left(2^{\prime} R, 4^{\prime} S\right)$ isomer $=$ ca $\left.50: 50\right)$ as a colorless solid. To this colorless solid was added ethyl acetate, and insoluble matter was filtrated off and ethyl acetate solution was concentrated under reduced pressure to afford mixture $\mathbf{5 a}\left(7.31 \mathrm{~g}, 60 \%\right.$ de $\left.\left(\left(2^{\prime} S, 4^{\prime} R\right):\left(2^{\prime} R, 4^{\prime} S\right)=80: 20\right)\right)$ as a colorless solid. ${ }^{1} \mathrm{H}$ NMR $\left(400 \mathrm{MHz}, \mathrm{CDCl}_{3}\right) \delta 6.72($ br s, $0.8 \mathrm{H}), 6.55(\mathrm{~d}, J=8.6 \mathrm{~Hz}$, $0.2 \mathrm{H}), 5.30-5.36(\mathrm{~m}, 1 \mathrm{H}), 4.58-4.65(\mathrm{~m}, 0.2 \mathrm{H}), 4.46(\mathrm{br} \mathrm{s}, 0.8 \mathrm{H}), 4.07-4.26$ (m, 5H), 3.95-3.98 (m, 0.8H), 3.90 (br s, $0.2 \mathrm{H}), 3.47-3.62(\mathrm{~m}, 2 \mathrm{H}), 3.31-3.41$ $(\mathrm{m}, 1 \mathrm{H}), 2.80-3.03(\mathrm{~m}, 1 \mathrm{H}), 2.55-2.70(\mathrm{~m}, 2 \mathrm{H}), 2.17(\mathrm{~s}, 3 \mathrm{H}), 1.96-2.04(\mathrm{~m}$, $1 \mathrm{H}), 1.78-1.88(\mathrm{~m}, 1 \mathrm{H}), 1.61-1.74(\mathrm{~m}, 1 \mathrm{H}), 1.44-1.49(\mathrm{~m}, 9 \mathrm{H}), 1.28-1.38(\mathrm{~m}$, $4 \mathrm{H}), 1.20-1.24(\mathrm{~m}, 3 \mathrm{H}), 0.91(\mathrm{t}, J=7.3 \mathrm{~Hz}, 3 \mathrm{H})$.
\end{abstract}

\begin{abstract}
Methyl 6-N-[(2'S, $\left.4^{\prime} R\right)-1^{\prime}-N-($ tert-butoxycarbonyl)-4'
ethylpiperidine-2'-carbonyl]- 2,3,4-tris- $O$-(trimethylsilyl)- $\alpha$ thiolincosaminide $(6 a)$

To a solution of mixture $5 \mathbf{a}\left(7.31 \mathrm{~g}, 14.8 \mathrm{mmol}, 60 \%\right.$ de $\left(\left(2^{\prime} S, 4^{\prime} R\right):\left(2^{\prime} R, 4^{\prime}\right.\right.$ $S)=80: 20))$ in pyridine $(38 \mathrm{ml})$ were added trimethylchlorosilane $(8.0 \mathrm{ml}$, $6.3 \mathrm{mmol})$ and hexamethyldisilazane $(6.0 \mathrm{ml}, 2.8 \mathrm{mmol})$, and stirred at room temperature for overnight. The mixture was added to saturated aqueous $\mathrm{NaHCO}_{3}$ and was extracted with ethyl acetate, washed with brine. The organic phase was dried over $\mathrm{Na}_{2} \mathrm{SO}_{4}$, filtrated and concentrated under reduced pressure. To the resulting residue were added methanol $(45 \mathrm{ml})$ and $6 \mathrm{~N}$ acetic acid $(2.7 \mathrm{ml})$, and stirred at room temperature for $3 \mathrm{~h}$. The mixture was added to saturated aqueous $\mathrm{NaHCO}_{3}$ and concentrated under reduced pressure. The resulting mixture was extracted with ethyl acetate, dried over $\mathrm{Na}_{2} \mathrm{SO}_{4}$, filtrated and concentrated under reduced pressure. The resulting residue was purified by silica gel column chromatography (hexane/ethyl acetate $=19 / 1$ to 3/1) to afford 6a (5.56 g, 30\% from ( \pm )-4a) as a colorless solid. ${ }^{1} \mathrm{H}$ NMR $\left(400 \mathrm{MHz}, \mathrm{CDCl}_{3}\right)$ $\delta 6.40(\mathrm{~d}, J=9.2 \mathrm{~Hz}, 1 \mathrm{H}), 5.17(\mathrm{~d}, J=5.5 \mathrm{~Hz}, 1 \mathrm{H}), 4.30-4.38(\mathrm{~m}, 1 \mathrm{H}), 4.19(\mathrm{dd}$, $J=9.0,6.3 \mathrm{~Hz}, 1 \mathrm{H}), 4.12(\mathrm{dd}, J=9.5,5.5 \mathrm{~Hz}, 1 \mathrm{H}), 4.07(\mathrm{~d}, J=8.3 \mathrm{~Hz}, 1 \mathrm{H})$, 3.93-4.02 (m, $1 \mathrm{H}), 3.90-3.93(\mathrm{~m}, 1 \mathrm{H}), 3.62(\mathrm{dd}, J=9.5,2.6 \mathrm{~Hz}, 1 \mathrm{H}), 3.48-3.59$ $(\mathrm{m}, 1 \mathrm{H}), 3.31-3.40(\mathrm{~m}, 1 \mathrm{H}), 2.83-2.89(\mathrm{~m}, 1 \mathrm{H}), 2.05(\mathrm{~s}, 3 \mathrm{H}), 1.99-2.03(\mathrm{~m}$, $1 \mathrm{H}), \quad 1.78-1.89(\mathrm{~m}, 1 \mathrm{H}), 1.57-1.63(\mathrm{~m}, 1 \mathrm{H}), 1.47(\mathrm{~s}, 9 \mathrm{H}), 1.29-1.39$ $(\mathrm{m}, 2 \mathrm{H}), 1.20-1.29(\mathrm{~m}, 1 \mathrm{H}), 1.17(\mathrm{~d}, J=6.4 \mathrm{~Hz}, 3 \mathrm{H}), 0.90(\mathrm{t}, J=7.3 \mathrm{~Hz}$, $3 \mathrm{H}), 0.19$ (s, 9H), 0.13-0.16 (m, 18H); MS (ESI) $\mathrm{m} / z 709(\mathrm{M}+\mathrm{H})^{+}$.
\end{abstract}

Methyl 6- $N-\left[\left(2^{\prime} R, 4^{\prime} S\right)-1^{\prime}-N\right.$-(tert-butoxycarbonyl)-4'-(n-propyl) piperidine- $2^{\prime}$-carbonyl] $-\alpha$-thiolincosaminide $\left(5 b^{\prime}\right)$ and mixture $5 b$ of methyl 6-N-[(2'S, $\left.4^{\prime} R\right)-1^{\prime}-N$-(tert-butoxycarbonyl)-4'-(n-propyl) piperidine-2'-carbonyl $]-\alpha$-thiolincosaminide and methyl $6-N-\left[\left(2^{\prime} R\right.\right.$, $\left.4^{\prime} S\right)-1^{\prime}-N$-(tert-butoxycarbonyl)-4' - (n-propyl)piperidine-2' carbonyl]- $\alpha$-thiolincosaminide

Compound $( \pm)-\mathbf{4 b}(11.7 \mathrm{~g}, 43.1 \mathrm{mmol})$, 1-hydroxybenzotriazole $(7.55 \mathrm{~g}$, $55.8 \mathrm{mmol}), N, N^{\prime}$-dicyclohexylcarbodiimide $(11.0 \mathrm{~g}, 53.3 \mathrm{mmol})$ and methyl $\alpha$-thiolincosaminide $(14.2 \mathrm{~g}, 56.1 \mathrm{mmol})$ in $N, N^{\prime}$-dimethylformamide $(100 \mathrm{ml})$ were treated for $12 \mathrm{~h}$ according to the similar procedure as described for the preparation of mixture 5a to afford methyl $6-N-\left[1^{\prime}-N\right.$ - (tert-butoxycarbonyl) $-4^{\prime}-$ ( $n$-propyl)piperidine- $2^{\prime}$-carbonyl]- $\alpha$-thiolincosaminide $\left(18.5 \mathrm{~g}, 84.9 \%,\left(2^{\prime} S, 4^{\prime}\right.\right.$ $R)$ isomer: $\left(2^{\prime} R, 4^{\prime} S\right)$ isomer $\left.=c a .50: 50\right)$ as a colorless solid. To this colorless solid was added ethyl acetate and insoluble matter was collected by filtration to afford $\mathbf{5} \mathbf{b}^{\prime}(3.2 \mathrm{~g}, 15 \%)$ as a colorless solid and ethyl acetate solution was concentrated under reduced pressure to afford mixture $5 \mathbf{b}(13.5 \mathrm{~g}, 62 \%, 20 \%$

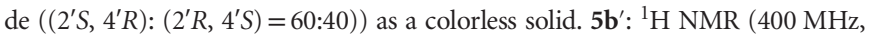
$\left.\mathrm{CDCl}_{3}\right) \delta 6.55(\mathrm{~d}, J=8.6 \mathrm{~Hz}, 1 \mathrm{H}), 5.34(\mathrm{~d}, J=5.5 \mathrm{~Hz}, 1 \mathrm{H}), 4.62(\mathrm{br} \mathrm{s}, 1 \mathrm{H})$, 4.11-4.27 (m, 4H), 3.99 (d, $J=9.4 \mathrm{~Hz}, 1 \mathrm{H}), 3.90$ (br s, $1 \mathrm{H}), 3.48-3.57(\mathrm{~m}, 2 \mathrm{H})$, 3.32-3.42 (m, 1H), 2.85-2.94 (m, 2H), 2.64 (br s, 1H), 2.16 (s, 3H), 1.94-2.03 $(\mathrm{m}, 1 \mathrm{H}), 1.77-1.87(\mathrm{~m}, 1 \mathrm{H}), 1.62-1.69(\mathrm{~m}, 1 \mathrm{H}), 1.50-1.59(\mathrm{~m}, 1 \mathrm{H}), 1.47(\mathrm{~s}$, 9H), $1.23-1.38(\mathrm{~m}, 5 \mathrm{H}), 1.22(\mathrm{~d}, J=6.4 \mathrm{~Hz}, 3 \mathrm{H}), 0.89(\mathrm{t}, J=6.9 \mathrm{~Hz}, 3 \mathrm{H})$; MS (ESI) $\mathrm{m} / z 507(\mathrm{M}+\mathrm{H})^{+} .5 \mathbf{b}:{ }^{1} \mathrm{H} \mathrm{NMR}\left(400 \mathrm{MHz}, \mathrm{CDCl}_{3}\right) \delta 6.74$ (br s, $\left.0.6 \mathrm{H}\right)$, $6.54(\mathrm{~d}, J=8.7 \mathrm{~Hz}, 0.4 \mathrm{H}), 5.30-5.35(\mathrm{~m}, 1 \mathrm{H}), 4.60$ (br s, $0.4 \mathrm{H}), 4.45$ (br s, $0.6 \mathrm{H}), 3.88-4.27(\mathrm{~m}, 6 \mathrm{H}), 3.47-3.62(\mathrm{~m}, 2 \mathrm{H}), 3.28-3.42(\mathrm{~m}, 1 \mathrm{H}), 2.61-3.06$ $(\mathrm{m}, 3 \mathrm{H}) 2.16(\mathrm{~m}, 3 \mathrm{H}), 1.92-2.02(\mathrm{~m}, 1 \mathrm{H}), 1.74-1.86(\mathrm{~m}, 1 \mathrm{H}), 1.61-1.67(\mathrm{~m}$, $1 \mathrm{H}), 1.49-1.54(\mathrm{~m}, 1 \mathrm{H}), 1.42-1.49(\mathrm{~m}, 9 \mathrm{H}), 1.25-1.37$ (m, 5H), 1.19-1.25 (m, $3 \mathrm{H}), 0.86-0.91(\mathrm{~m}, 3 \mathrm{H})$.

Methyl 6-N-[(2'S, $\left.4^{\prime} R\right)-1^{\prime}-N$-(tert-butoxycarbonyl)-4'-(n-propyl) piperidine-2' -carbonyl]-2,3,4-tris- $O$-(trimethylsilyl)- $\alpha$ -

thiolincosaminide $(6 \mathrm{~b})$

Mixture 5b (13.5 g, $26.6 \mathrm{mmol}, 20 \%$ de $\left(\left(2^{\prime} S, 4^{\prime} R\right):\left(2^{\prime} R, 4^{\prime} S\right)=60: 40\right)$, trimethylchlorosilane $(17.0 \mathrm{ml}, 133 \mathrm{mmol})$ and hexamethyldisilazane $(27.9 \mathrm{ml}, 133 \mathrm{mmol})$ in pyridine $(50 \mathrm{ml})$ were treated for 40 min according to the similar procedure as described for the preparation of $\mathbf{6 a}$ and the crude tetrakis-O-trimethylsilyl intermediate and $6 \mathrm{~N}$ acetic acid $(5.8 \mathrm{ml})$ in $\mathrm{MeOH}$ $(138 \mathrm{ml})$ were treated for $2.5 \mathrm{~h}$ according to the similar procedure as described for the preparation of $\mathbf{6 a}$ to afford $\mathbf{6 b}(9.28 \mathrm{~g}, 48 \%$ in 2 steps from diastereomeric mixture 5b) as a colorless solid. ${ }^{1} \mathrm{H}$ NMR $\left(400 \mathrm{MHz}, \mathrm{CDCl}_{3}\right)$ $\delta 6.36(\mathrm{~d}, J=9.4 \mathrm{~Hz}, 1 \mathrm{H}), 5.17(\mathrm{~d}, J=5.5 \mathrm{~Hz}, 1 \mathrm{H}), 4.30-4.37(\mathrm{~m}, 1 \mathrm{H}), 4.09-$ $4.19(\mathrm{~m}, 2 \mathrm{H}), 4.06(\mathrm{~d}, J=8.3 \mathrm{~Hz}, 1 \mathrm{H}), 3.95-4.03(\mathrm{~m}, 1 \mathrm{H}), 3.98-3.92(\mathrm{~m}, 1 \mathrm{H})$, $3.61(\mathrm{dd}, J=9.5,2.6 \mathrm{~Hz}, 1 \mathrm{H}), 3.44-3.55(\mathrm{~m}, 1 \mathrm{H}), 3.3-3.41(\mathrm{~m}, 1 \mathrm{H}), 2.92(\mathrm{~d}$, $J=6.5 \mathrm{~Hz}, 1 \mathrm{H}), 2.06$ (s, 3H), 2.00-2.05 (m, 1H), 1.78-1.90 (m, 1H), 1.49-1.64 $(\mathrm{m}, 2 \mathrm{H}), 1.42-1.49(\mathrm{~m}, 9 \mathrm{H}), 1.20-1.37(\mathrm{~m}, 5 \mathrm{H}), 1.17(\mathrm{~d}, J=6.4 \mathrm{~Hz}, 3 \mathrm{H}), 0.85-$ $0.92(\mathrm{~m}, 3 \mathrm{H}), 0.19-0.20(\mathrm{~m}, 9 \mathrm{H}), 0.13-0.15(\mathrm{~m}, 18 \mathrm{H})$; MS (ESI) $\mathrm{m} / z 723$ $(\mathrm{M}+\mathrm{H})^{+}$.

Methyl 6-N-[(2'R, $\left.4^{\prime} S\right)-1^{\prime}-N-($ tert-butoxycarbonyl)-4'-(n-propyl) piperidine-2'-carbonyl]-2,3,4-tris- $O$-(trimethylsilyl)- $\alpha$ thiolincosaminide $\left(6 \mathbf{b}^{\prime}\right)$

Compound $5 \mathbf{b}^{\prime} \quad(1.00 \mathrm{~g}, 1.97 \mathrm{mmol})$, trimethylchlorosilane $(1.26 \mathrm{ml}$, $9.87 \mathrm{mmol})$ and hexamethyldisilazane $(2.07 \mathrm{ml}, 9.87 \mathrm{mmol})$ in pyridine $(4.0 \mathrm{ml})$ were treated for $30 \mathrm{~min}$ according to the similar procedure as described for the preparation of $\mathbf{6 a}$ and the crude tetrakis- $O$-trimethylsilyl intermediate was treated with $6 \mathrm{~N}$ acetic acid $(0.42 \mathrm{ml})$ in $\mathrm{MeOH}(10 \mathrm{ml})$ for $1 \mathrm{~h}$ according to the similar procedure as described for the preparation of $\mathbf{6 a}$ to afford $\mathbf{6} \mathbf{b}^{\prime}$ (926 mg, 65\% in 2 steps) as a colorless solid. ${ }^{1} \mathrm{H}$ NMR $(400 \mathrm{MHz}$, $\left.\mathrm{CDCl}_{3}\right) \delta 6.56(\mathrm{~d}, J=8.9 \mathrm{~Hz}, 1 \mathrm{H}), 5.21(\mathrm{~d}, J=5.5 \mathrm{~Hz}, 1 \mathrm{H}), 4.24-4.31(\mathrm{~m}, 1 \mathrm{H})$, $4.11-4.20(\mathrm{~m}, 2 \mathrm{H}), 4.08(\mathrm{~d}, J=8.1 \mathrm{~Hz}, 1 \mathrm{H}), 4.02-4.04(\mathrm{~m}, 1 \mathrm{H}), 3.63(\mathrm{dd}$, $J=9.5,2.6 \mathrm{~Hz}, 1 \mathrm{H}), 3.32-3.51(\mathrm{~m}, 3 \mathrm{H}), 2.04(\mathrm{~s}, 3 \mathrm{H}), 1.86-1.93(\mathrm{~m}, 1 \mathrm{H}), 1.70-$ $1.85(\mathrm{~m}, 2 \mathrm{H}), 1.44-1.49(\mathrm{~m}, 10 \mathrm{H}), 1.21-1.38(\mathrm{~m}, 5 \mathrm{H}), 1.15(\mathrm{~d}, J=6.5 \mathrm{~Hz}, 3 \mathrm{H})$, $0.89(\mathrm{t}, J=6.9 \mathrm{~Hz}, 3 \mathrm{H}), 0.19(\mathrm{~s}, 9 \mathrm{H}), 0.15(\mathrm{~s}, 9 \mathrm{H}), 0.14(\mathrm{~s}, 9 \mathrm{H}) ; \mathrm{MS}(\mathrm{ESI}) \mathrm{m} / \mathrm{z}$ $723(\mathrm{M}+\mathrm{H})^{+}$.

Mixture 5c of methyl 6-N-[(2'S, $\left.4^{\prime} R\right)-1^{\prime}-N$-(tert-butoxycarbonyl) $-4^{\prime}-$ (n-butyl)piperidine-2'-carbonyl]- $\alpha$-thiolincosaminide and methyl 6- 
$N-\left[\left(2^{\prime} R, 4^{\prime} S\right)-1^{\prime}-N\right.$-(tert-butoxycarbonyl)-4' -(n-butyl)piperidine-2' carbonyl]- $\alpha$-thiolincosaminide

Compound $( \pm)-4 \mathrm{c}(12.6 \mathrm{~g}, 44.2 \mathrm{mmol})$, 1-hydroxybenzotriazole $(7.77 \mathrm{~g}$ $57.5 \mathrm{mmol}), N, N^{\prime}$-dicyclohexylcarbodiimide $(11.0 \mathrm{~g}, 53.3 \mathrm{mmol})$ and methyl $\alpha$-thiolincosaminide $(14.6 \mathrm{~g}, 57.5 \mathrm{mmol})$ in $N, N^{\prime}$-dimethylformamide $(120 \mathrm{ml})$ were treated for $20 \mathrm{~h}$ according to the similar procedure as described for the preparation of mixture $5 \mathbf{a}$ to afford methyl $6-\mathrm{N}-\left[1^{\prime}-\mathrm{N}\right.$-(tert-butoxycarbonyl)- $4^{\prime}-$ (n-butyl)piperidine-2'-carbonyl]- $\alpha$-thiolincosaminide $\left(20.0 \mathrm{~g}, 87 \%,\left(2^{\prime} S, 4^{\prime} R\right)\right.$ isomer: $\left(2^{\prime} R, 4^{\prime} S\right)$ isomer $=$ ca 50:50) as a colorless solid. To this colorless solid $(14.5 \mathrm{~g})$ was added ethyl acetate and insoluble matter was filtrated off and ethyl acetate solution was concentrated under reduced pressure to afford mixture $5 \mathrm{c}$ $\left(8.15 \mathrm{~g}, 80 \%\right.$ de $\left.\left(\left(2^{\prime} S, 4^{\prime} R\right):\left(2^{\prime} R, 4^{\prime} S\right)=90: 10\right)\right)$ as a colorless solid. ${ }^{1} \mathrm{H}$ NMR $\left(400 \mathrm{MHz}, \mathrm{CDCl}_{3}\right) \delta 6.85$ (br s, $\left.0.9 \mathrm{H}\right), 6.58(\mathrm{~d}, J=8.7 \mathrm{~Hz}, 0.1 \mathrm{H}), 5.30-5.34(\mathrm{~m}$, $1 \mathrm{H}), 4.64(\mathrm{br} \mathrm{s}, 0.1 \mathrm{H}), 4.46$ (br s, $0.9 \mathrm{H}), 3.93-4.25(\mathrm{~m}, 6 \mathrm{H}), 3.51-3.63(\mathrm{~m}, 2 \mathrm{H})$, $3.28-3.38(\mathrm{~m}, 1 \mathrm{H}), 2.80-2.98(\mathrm{~m}, 2 \mathrm{H}), 2.14-2.16(\mathrm{~m}, 3 \mathrm{H}), 1.93-2.02(\mathrm{~m}, 1 \mathrm{H})$, $1.68-1.86(\mathrm{~m}, 3 \mathrm{H}), 1.54$ (br s, $1 \mathrm{H}), 1.44-1.47(\mathrm{~m}, 9 \mathrm{H}), 1.19-1.35(\mathrm{~m}, 7 \mathrm{H})$, $1.19-1.25(\mathrm{~m}, 3 \mathrm{H}), 0.86-0.91(\mathrm{~m}, 3 \mathrm{H})$.

\section{Methyl 6-N-[(2'S, $\left.4^{\prime} R\right)-1^{\prime}-N$-(tert-butoxycarbonyl)-4'-(n-butyl) piperidine-2'-carbonyl]-2,3,4-tris-O-(trimethylsilyl)- $\alpha$ - \\ thiolincosaminide $(6 \mathrm{c})$}

Mixture 5c $\left(8.15 \mathrm{~g}, 15.7 \mathrm{mmol}, 80 \%\right.$ de $\left(\left(2^{\prime} S, 4^{\prime} R\right):\left(2^{\prime} R, 4^{\prime} S\right)=90: 10\right)$, trimethylchlorosilane $(100 \mathrm{ml}, \quad 78.3 \mathrm{mmol})$ and hexamethyldisilazane $(16.4 \mathrm{ml}, 78.3 \mathrm{mmol})$ in pyridine $(30 \mathrm{ml})$ were treated for $20 \mathrm{~min}$ according to the similar procedure as described for the preparation of $\mathbf{6 a}$ and the crude tetrakis-O-trimethylsilyl intermediate and $6 \mathrm{~N}$ acetic acid $(3.4 \mathrm{ml})$ in $\mathrm{MeOH}$ $(88 \mathrm{ml})$ were treated for $40 \mathrm{~min}$ according to the similar procedure as described for the preparation of $\mathbf{6 a}$ to afford $\mathbf{6 c}(8.20 \mathrm{~g}, 71 \%$ in 2 steps from diastereomeric mixture $5 \mathrm{c})$ as a colorless solid. ${ }^{1} \mathrm{H}$ NMR $\left(400 \mathrm{MHz}, \mathrm{CDCl}_{3}\right)$ $\delta 6.34(\mathrm{~d}, J=9.3 \mathrm{~Hz}, 1 \mathrm{H}), 5.17(\mathrm{~d}, J=5.5 \mathrm{~Hz}, 1 \mathrm{H}), 4.30-4.36(\mathrm{~m}, 1 \mathrm{H}), 4.09-$ $4.15(\mathrm{~m}, 2 \mathrm{H}), 4.05(\mathrm{~d}, J=8.3 \mathrm{~Hz}, 1 \mathrm{H}), 3.95-4.03(\mathrm{~m}, 1 \mathrm{H}), 3.88-3.90(\mathrm{~m}, 1 \mathrm{H})$, $3.61(\mathrm{dd}, J=9.5,2.6 \mathrm{~Hz}, 1 \mathrm{H}), 3.43-3.44(\mathrm{~m}, 1 \mathrm{H}), 3.32-3.44(\mathrm{~m}, 1 \mathrm{H}), 2.96(\mathrm{~d}$, $J=6.5 \mathrm{~Hz}, 1 \mathrm{H}), 2.05(\mathrm{~s}, 3 \mathrm{H}), 2.00-2.04(\mathrm{~m}, 1 \mathrm{H}), 1.79-1.89(\mathrm{~m}, 1 \mathrm{H}), 1.49-1.87$ (m, 1H), $1.46(\mathrm{~s}, 9 \mathrm{H}), 1.19-1.33(\mathrm{~m}, 7 \mathrm{H}), 1.16(\mathrm{~d}, J=6.4 \mathrm{~Hz}, 3 \mathrm{H}), 0.85-0.92$ (m, 3H), 0.17-0.19 (m, 9H), 0.12-0.15 (m, 18H); MS (ESI) $\mathrm{m} / \mathrm{z} 737(\mathrm{M}+\mathrm{H})^{+}$.

\section{Methyl (7S)-7-deoxy-6- $N-\left[\left(2^{\prime} S, 4^{\prime} R\right)-4^{\prime}\right.$-ethylpiperidine-2'- carbonyl]-7-[5-(2-nitrophenyl)-1,3,4-thiadiazol-2-yl-thio]- $\alpha$ - thiolincosaminide $(7 \mathrm{a})$}

To a solution of $6 \mathrm{a}(270 \mathrm{mg}, 0.381 \mathrm{mmol})$ in tetrahydrofuran $(5 \mathrm{ml})$ at $0{ }^{\circ} \mathrm{C}$ were added triphenylphosphine $(200 \mathrm{mg}, 0.762 \mathrm{mmol}$ ) and diethlazodicarboxylate $(0.150 \mathrm{ml}, 0.823 \mathrm{mmol})$, and stirred at $0{ }^{\circ} \mathrm{C}$ for $10 \mathrm{~min}$, and 5 - $(2$ nitrophenyl)-1,3,4-thiadiazole-2-thiol $(200 \mathrm{mg}, 0.836 \mathrm{mmol})$ was added and stirred at room temperature for $3 \mathrm{~h}$. The mixture was concentrated under reduced pressure and added methanol $(10 \mathrm{ml}), 5 \mathrm{~N}$ hydrochloric acid $(0.1 \mathrm{ml})$ and stirred at room temperature for $1 \mathrm{~h}$. The mixture was concentrated under reduced pressure. To the resulting residue was added trifluoroacetic acid $(3.0 \mathrm{ml})$ and stirred at room temperature for $30 \mathrm{~min}$. The mixture was concentrated under reduced pressure and the resulting residue was purified by preparative TLC $\left(\mathrm{CHCl}_{3} / \mathrm{CH}_{3} \mathrm{OH} / 28 \%\right.$ aq $\left.\mathrm{NH}_{4} \mathrm{OH}=20 / 1 / 0.1\right)$ to afford $7 \mathbf{a}$ $(52.5 \mathrm{mg}, 22 \%)$ as colorless solid. $[\alpha]_{\mathrm{D}}{ }^{25}+100^{\circ}\left(c 1.3, \mathrm{CH}_{3} \mathrm{OH}\right) ;{ }^{1} \mathrm{H}$ NMR $\left(400 \mathrm{MHz}, \mathrm{CD}_{3} \mathrm{OD}\right) \delta 8.10(\mathrm{~d}, J=7.6 \mathrm{~Hz}, 1 \mathrm{H}), 7.76-7.86(\mathrm{~m}, 3 \mathrm{H}), 5.28(\mathrm{~d}$, $J=5.6 \mathrm{~Hz}, 1 \mathrm{H}), 4.67(\mathrm{dd}, J=10.1,2.5 \mathrm{~Hz}, 1 \mathrm{H}), 4.46(\mathrm{qd}, J=6.8,2.5 \mathrm{~Hz}, 1 \mathrm{H})$, 4.38-4.43 (m, $1 \mathrm{H}), 4.07-4.12(\mathrm{~m}, 1 \mathrm{H}), 3.87-3.89(\mathrm{~m}, 1 \mathrm{H}), 3.56(\mathrm{dd}, J=10.4$, $3.3 \mathrm{~Hz}, 1 \mathrm{H}), 3.26-3.31(\mathrm{~m}, 1 \mathrm{H}), 3.13-3.20(\mathrm{~m}, 1 \mathrm{H}), 2.56-2.67(\mathrm{~m}, 1 \mathrm{H}), 1.99(\mathrm{~s}$, $3 \mathrm{H}), 1.95-1.98(\mathrm{~m}, 1 \mathrm{H}), 1.68-1.75(\mathrm{~m}, 1 \mathrm{H}), 1.56(\mathrm{~d}, J=6.8 \mathrm{~Hz}, 3 \mathrm{H}), 1.36-1.50$ (m, 1H), 1.25-1.34 (m, 2H), 0.98-1.11 (m, 2H), 0.89-0.95 (m, 3H); MS (FAB) $m / z 614(\mathrm{M}+\mathrm{H})^{+}$; HRMS (ESI) $\mathrm{m} / z$ calcd for $\mathrm{C}_{25} \mathrm{H}_{36} \mathrm{~N}_{5} \mathrm{O}_{7} \mathrm{~S}_{3} 614.1771$, found $614.1768(\mathrm{M}+\mathrm{H})^{+}$.

Methyl (7S)-7-deoxy-7-[5-(2-nitrophenyl)-1,3,4-thiadiazol-2-ylthio $]-6-N-\left[\left(2^{\prime} S, 4^{\prime} R\right)-4^{\prime}-(n\right.$-propyl)piperidine-2' -carbonyl $]-\alpha-$ thiolincosaminide $(7 \mathrm{~b})$

Reaction of $\mathbf{6 b}$ (200 mg, $0.277 \mathrm{mmol}$ ) with 5-(2-nitrophenyl)-1,3,4-thiadiazole2-thiol (114 mg, $0.476 \mathrm{mmol}$ ) afforded $\mathbf{7 b}$ as a colorless solid in $24 \%$ yield by the similar procedure to $7 \mathrm{a} .[\alpha]_{\mathrm{D}}{ }^{26}+83^{\circ}\left(c 0.17, \mathrm{CH}_{3} \mathrm{OH}\right) ;{ }^{1} \mathrm{H} \mathrm{NMR}(400 \mathrm{MHz}$, $\left.\mathrm{CD}_{3} \mathrm{OD}\right) \delta 8.09-8.13(\mathrm{~m}, 1 \mathrm{H}), 7.77-7.86(\mathrm{~m}, 3 \mathrm{H}), 5.29(\mathrm{~d}, J=5.6 \mathrm{~Hz}, 1 \mathrm{H})$, $4.63-4.69(\mathrm{~m}, 1 \mathrm{H}), 4.41-4.47(\mathrm{~m}, 1 \mathrm{H}), 4.43(\mathrm{~d}, J=10.2 \mathrm{~Hz}, 1 \mathrm{H}), 4.06-4.12(\mathrm{~m}$, $1 \mathrm{H}), 3.87-3.91(\mathrm{~m}, 1 \mathrm{H}), 3.56(\mathrm{dd}, J=10.2,3.4 \mathrm{~Hz}, 1 \mathrm{H}), 3.25-3.31(\mathrm{~m}, 1 \mathrm{H})$, 3.19-3.25 (m, 1H), 3.08-3.18 (m, 1H), 2.58-2.68 (m, 1H), $1.99(\mathrm{~s}, 3 \mathrm{H}), 1.65-$ $1.72(\mathrm{~m}, 1 \mathrm{H}), 1.56(\mathrm{~d}, J=7.1 \mathrm{~Hz}, 3 \mathrm{H}), 1.24-1.34(\mathrm{~m}, 5 \mathrm{H}), 0.98-1.11(\mathrm{~m}, 2 \mathrm{H})$, 0.85-0.95 (m, 3H); MS (FAB) $\mathrm{m} / z 628(\mathrm{M}+\mathrm{H})^{+}$; HRMS (ESI) $\mathrm{m} / z$ calcd for $\mathrm{C}_{26} \mathrm{H}_{38} \mathrm{~N}_{5} \mathrm{O}_{7} \mathrm{~S}_{3} 628.1928$, found $628.1926(\mathrm{M}+\mathrm{H})^{+}$.

Methyl (7S)-7-deoxy-7-[5-(2-nitrophenyl)-1,3,4-thiadiazol-2-ylthio]- 6-N-[(2'R, $\left.4^{\prime} S\right)-4^{\prime}$-(n-propyl)piperidine-2-carbonyl $]-\alpha-$ thiolincosaminide $\left(7 \mathbf{b}^{\prime}\right)$

Reaction of $\mathbf{6} \mathbf{b}^{\prime}$ (200 $\left.\mathrm{mg}, 0.277\right) \mathrm{mmol}$ ) with 5-(2-nitrophenyl)-1,3,4-thiadiazole-2-thiol (104 mg, $0.435 \mathrm{mmol}$ ) afforded $7 \mathbf{b}^{\prime}$ as a light yellow solid in $25 \%$ yield by the similar procedure to $7 \mathrm{a}$. $[\alpha]_{\mathrm{D}}{ }^{26}+110^{\circ}\left(\mathrm{c} 0.21, \mathrm{CH}_{3} \mathrm{OH}\right) ;{ }^{1} \mathrm{H} \mathrm{NMR}$ $\left(400 \mathrm{MHz}, \mathrm{CD}_{3} \mathrm{OD}\right) \delta 8.08-8.12(\mathrm{~m}, 1 \mathrm{H}), 7.75-7.85(\mathrm{~m}, 3 \mathrm{H}), 5.27(\mathrm{~d}$, $J=5.9 \mathrm{~Hz}, 1 \mathrm{H}), 4.66(\mathrm{dd}, J=10.1,2.5 \mathrm{~Hz}, 1 \mathrm{H}), 4.39-4.49(\mathrm{~m}, 2 \mathrm{H}), 4.07-$ $4.13(\mathrm{~m}, 1 \mathrm{H}), 3.83-3.85(\mathrm{~m}, 1 \mathrm{H}), 3.56(\mathrm{dd}, J=10.2,3.3 \mathrm{~Hz}, 1 \mathrm{H}), 3.24-3.29(\mathrm{~m}$, $1 \mathrm{H}), 3.09-3.15(\mathrm{~m}, 1 \mathrm{H}), 2.58-2.66(\mathrm{~m}, 1 \mathrm{H}), 2.01(\mathrm{~s}, 3 \mathrm{H}), 1.94-1.99(\mathrm{~m}, 1 \mathrm{H})$, $1.65-1.73(\mathrm{~m}, 1 \mathrm{H}), 1.58(\mathrm{~d}, J=6.9 \mathrm{~Hz}, 3 \mathrm{H}), 1.18-1.42(\mathrm{~m}, 5 \mathrm{H}), 0.99-1.12(\mathrm{~m}$, $2 \mathrm{H}), 0.90(\mathrm{t}, J=7.2 \mathrm{~Hz}, 3 \mathrm{H})$; MS (FAB) $\mathrm{m} / z 628(\mathrm{M}+\mathrm{H})^{+}$; HRMS (ESI) $\mathrm{m} / z$ calcd for $\mathrm{C}_{26} \mathrm{H}_{38} \mathrm{~N}_{5} \mathrm{O}_{7} \mathrm{~S}_{3} 628.1928$, found $628.1921(\mathrm{M}+\mathrm{H})^{+}$.

Methyl (7S)-6- $N$-[(2'S, 4'R)-4'-(n-butyl)piperidine-2'-carbonyl $]-7-$ deoxy-7-[5-(2-nitrophenyl)-1,3,4-thiadiazol-2-yl-thio]- $\alpha$ -

thiolincosaminide $(7 \mathrm{c})$

Reaction of $6 \mathbf{c}(500 \mathrm{mg}, 0.678 \mathrm{mmol})$ with 5-(2-nitrophenyl)-1,3,4-thiadiazole2-thiol $(211 \mathrm{mg}, 0.882 \mathrm{mmol})$ afforded $7 \mathrm{c}$ as a colorless solid in $21 \%$ yield by the similar procedure to $7 \mathrm{a}$. $[\alpha]_{\mathrm{D}}{ }^{25}+93^{\circ}\left(c 0.48, \mathrm{CH}_{3} \mathrm{OH}\right) ;{ }^{1} \mathrm{H} \mathrm{NMR}(400 \mathrm{MHz}$, $\left.\mathrm{CD}_{3} \mathrm{OD}\right) \delta 8.08-8.12(\mathrm{~m}, 1 \mathrm{H}), 7.76-7.87(\mathrm{~m}, 3 \mathrm{H}), 5.29(\mathrm{~d}, J=5.6 \mathrm{~Hz}, 1 \mathrm{H}), 4.68$ (dd, $J=10.1,2.3 \mathrm{~Hz}, 1 \mathrm{H}), 4.46(\mathrm{dd}, J=6.8,2.4 \mathrm{~Hz}, 1 \mathrm{H}), 4.42(\mathrm{~d}, J=10.2 \mathrm{~Hz}$, $1 \mathrm{H}), 4.11(\mathrm{dd}, J=10.2,5.6 \mathrm{~Hz}, 1 \mathrm{H}), 3.88-3.91(\mathrm{~m}, 1 \mathrm{H}), 3.59-3.63(\mathrm{~m}, 1 \mathrm{H})$, $3.57(\mathrm{dd}, J=10.2,3.2 \mathrm{~Hz}, 1 \mathrm{H}), 3.38(\mathrm{dd}, J=11.9,2.9 \mathrm{~Hz}, 1 \mathrm{H}), 3.15-3.22(\mathrm{~m}$, $1 \mathrm{H}), 2.63-2.72(\mathrm{~m}, 1 \mathrm{H}), 1.99(\mathrm{~s}, 3 \mathrm{H}), 1.68-1.76(\mathrm{~m}, 1 \mathrm{H}), 1.52-1.58(\mathrm{~m}, 4 \mathrm{H})$, $1.24-1.34(\mathrm{~m}, 6 \mathrm{H}), 1.02-1.17(\mathrm{~m}, 3 \mathrm{H}), 0.84-0.92(\mathrm{~m}, 3 \mathrm{H})$; MS (FAB) $\mathrm{m} / z 642$ $(\mathrm{M}+\mathrm{H})^{+}$; HRMS (ESI) $\mathrm{m} / z$ calcd for $\mathrm{C}_{27} \mathrm{H}_{40} \mathrm{~N}_{5} \mathrm{O}_{7} \mathrm{~S}_{3} 642.2084$, found 642.2092 $(\mathrm{M}+\mathrm{H})^{+}$.

Methyl (7S)-7-deoxy-6- $N$ - $\left[\left(2^{\prime} S, 4^{\prime} R\right)-4^{\prime}\right.$-ethylpiperidine-2'carbonyl]-7-[5-(4-fluoro-2-nitrophenyl)-1,3,4-thiadiazol-2-yl-thio]$\alpha$-thiolincosaminide (7d)

Reaction of $\mathbf{6 a}(180 \mathrm{mg}, 0.253 \mathrm{mmol})$ with 5-(4-fluoro-2-nitrophenyl)-1,3,4thiadiazole-2-thiol $(80.0 \mathrm{mg}, 311 \mathrm{mmol})$ afforded $\mathbf{7 d}$ as a light yellow solid in $39 \%$ yield by the similar procedure to $7 \mathrm{a}$. $[\alpha]_{\mathrm{D}}{ }^{25}+89^{\circ}\left(c 0.53, \mathrm{CH}_{3} \mathrm{OH}\right) ;{ }^{1} \mathrm{H}$ $\operatorname{NMR}\left(400 \mathrm{MHz}, \mathrm{CD}_{3} \mathrm{OD}\right) \delta 7.98(\mathrm{dd}, J=8.3,2.5 \mathrm{~Hz}, 1 \mathrm{H}), 7.85(\mathrm{dd}, J=8.7$, $5.3 \mathrm{~Hz}, 1 \mathrm{H}$ ), 7.64 (ddd, $J=8.7,7.7,2.5 \mathrm{~Hz}, 1 \mathrm{H}), 5.27$ (d, $J=5.6 \mathrm{~Hz}, 1 \mathrm{H}), 4.67$ (dd, $J=10.0,2.4 \mathrm{~Hz}, 1 \mathrm{H}), 4.46(\mathrm{qd}, J=6.8,2.4 \mathrm{~Hz}, 1 \mathrm{H}), 4.41$ (dd, $J=10.1$, $0.9 \mathrm{~Hz}, 1 \mathrm{H}), 4.10(\mathrm{dd}, J=10.3,5.9 \mathrm{~Hz}, 1 \mathrm{H}), 3.88(\mathrm{dd}, J=3.2,0.9 \mathrm{~Hz}, 1 \mathrm{H}), 3.55$ (dd, $J=10.3,3.2 \mathrm{~Hz}, 1 \mathrm{H}), 3.26-3.30(\mathrm{~m}, 1 \mathrm{H}), 3.14-3.20(\mathrm{~m}, 1 \mathrm{H}), 2.64(\mathrm{td}$, $J=12.8,2.8 \mathrm{~Hz}, 1 \mathrm{H}), 1.99(\mathrm{~s}, 3 \mathrm{H}), 1.95-1.98(\mathrm{~m}, 1 \mathrm{H}), 1.68-1.75(\mathrm{~m}, 1 \mathrm{H}), 1.56$ $(\mathrm{d}, J=6.8 \mathrm{~Hz}, 3 \mathrm{H}), 1.37-1.50(\mathrm{~m}, 1 \mathrm{H}), 1.26-1.35(\mathrm{~m}, 2 \mathrm{H}), 1.00-1.11(\mathrm{~m}, 2 \mathrm{H})$, $0.92(\mathrm{t}, J=7.5 \mathrm{~Hz}, 3 \mathrm{H})$; MS (FAB) $\mathrm{m} / z 632(\mathrm{M}+\mathrm{H})^{+}$; HRMS (ESI) $\mathrm{m} / z$ calcd for $\mathrm{C}_{25} \mathrm{H}_{35} \mathrm{FN}_{5} \mathrm{O}_{7} \mathrm{~S}_{3}$ 632.1677, found $632.1674(\mathrm{M}+\mathrm{H})^{+}$.

Methyl (7S)-7-deoxy-6- $N$-[(2'S, 4'R)-4-ethyl-1'- $N$-methylpiperidine2 '-carbonyl]-7-[5-(4-fluoro-2-nitrophenyl)-1,3,4-thiadiazol-2-ylthio]- $\boldsymbol{\alpha}$-thiolincosaminide $(\mathbf{8 d})$

To a solution of compound $7 \mathbf{d}(52 \mathrm{mg}, 0.082 \mathrm{mmol})$ in $\mathrm{MeOH}(3 \mathrm{ml})$ at $0{ }^{\circ} \mathrm{C}$ were added $36 \%$ aqueous formaldehyde $(100 \mu \mathrm{l}, 1.2 \mathrm{mmol})$, acetic acid $(50 \mu \mathrm{l}$, $0.79 \mathrm{mmol})$ and $\mathrm{NaBH}(\mathrm{OAc})_{3}(120 \mathrm{mg}, 0.57 \mathrm{mmol})$ and stirred at room temperature for $4 \mathrm{~h}$. The mixture was concentrated under reduced pressure. Ethyl acetate was added to the residue and washed with saturated aqueous $\mathrm{NaHCO}_{3}$. The organic phase was dried over $\mathrm{MgSO}_{4}$, filtrated and concentrated under reduced pressure. The resulting residue was purified by preparative TLC $\left(\mathrm{CHCl}_{3} / \mathrm{MeOH} / 28 \%\right.$ aq $\left.\mathrm{NH}_{4} \mathrm{OH}=10 / 1 / 0.1\right)$ to afford $8 \mathbf{d}(41 \mathrm{mg}, 77 \%)$ as a 
light yellow solid. $[\alpha]_{\mathrm{D}}{ }^{25}+80^{\circ}\left(c 0.92, \mathrm{CH}_{3} \mathrm{OH}\right) ;{ }^{1} \mathrm{H}$ NMR $\left(400 \mathrm{MHz}, \mathrm{CD}_{3} \mathrm{OD}\right)$ $\delta 7.98$ (dd, $J=8.3,2.6 \mathrm{~Hz}, 1 \mathrm{H}), 7.85$ (dd, $J=8.7,5.3 \mathrm{~Hz}, 1 \mathrm{H}), 7.61-7.67$ (m, $1 \mathrm{H}), 5.28(\mathrm{~d}, J=5.6 \mathrm{~Hz}, 1 \mathrm{H}), 4.69(\mathrm{dd}, J=10.1,2.6 \mathrm{~Hz}, 1 \mathrm{H}), 4.48(\mathrm{qd}, J=6.9$, $2.6 \mathrm{~Hz}, 1 \mathrm{H}), 4.43(\mathrm{dd}, J=10.1,0.8 \mathrm{~Hz}, 1 \mathrm{H}), 4.12(\mathrm{dd}, J=10.2,5.6 \mathrm{~Hz}, 1 \mathrm{H})$, $3.83-3.87(\mathrm{~m}, 1 \mathrm{H}), 3.57(\mathrm{dd}, J=10.2,2.9 \mathrm{~Hz}, 1 \mathrm{H}), 2.93-3.99(\mathrm{~m}, 1 \mathrm{H}), 2.58-$ $2.64(\mathrm{~m}, 1 \mathrm{H}), 2.25(\mathrm{~s}, 3 \mathrm{H}), 2.06-2.15(\mathrm{~m}, 1 \mathrm{H}), 1.98-2.01(\mathrm{~m}, 3 \mathrm{H}), 1.85-1.91$ (m, $1 \mathrm{H}), 1.69-1.76(\mathrm{~m}, 1 \mathrm{H}), 1.58(\mathrm{~d}, J=6.9 \mathrm{~Hz}, 3 \mathrm{H}), 1.23-1.34(\mathrm{~m}, 5 \mathrm{H}), 0.87-$ $0.94(\mathrm{~m}, 3 \mathrm{H})$; MS (FAB) $\mathrm{m} / \mathrm{z} 646(\mathrm{M}+\mathrm{H})^{+}$; HRMS (ESI) $\mathrm{m} / \mathrm{z}$ calcd for $\mathrm{C}_{27} \mathrm{H}_{39} \mathrm{FN}_{5} \mathrm{O}_{7} \mathrm{~S}_{3}$ 646.1834, found $646.1833(\mathrm{M}+\mathrm{H})^{+}$.

Methyl (7S)-7-deoxy-7-[5-(4-fluoro-2-nitrophenyl)-1,3,4-thiadiazol2-yl-thio $]-6-N$ - $\left[\left(2^{\prime} S, 4^{\prime} R\right)-4^{\prime}\right.$-(n-propyl)piperidine-2'-carbonyl $]-\alpha-$ thiolincosaminide $(7 \mathrm{e})$

Reaction of $\mathbf{6 b}$ ( $2.80 \mathrm{~g}, 3.87 \mathrm{mmol})$ with 5-(4-fluoro-2-nitrophenyl)-1,3,4thiadiazole-2-thiol $(1.19 \mathrm{mg}, 4.59 \mathrm{mmol})$ afforded $7 \mathrm{e}$ as a light yellow solid in $39 \%$ yield by the similar procedure to $7 \mathbf{a}$ except for using toluene as a solvent of Mitunobu reaction. $[\alpha]_{\mathrm{D}}{ }^{26}+93^{\circ}\left(c 0.20, \mathrm{CH}_{3} \mathrm{OH}\right) ;{ }^{1} \mathrm{H} \mathrm{NMR}(400 \mathrm{MHz}$, $\left.\mathrm{CD}_{3} \mathrm{OD}\right) \delta 7.99(\mathrm{dd}, J=8.3,2,7 \mathrm{~Hz}, 1 \mathrm{H}), 7.85(\mathrm{dd}, J=8.6,5.2 \mathrm{~Hz}, 1 \mathrm{H}), 7.60-$ $7.69(\mathrm{~m}, 1 \mathrm{H}), 5.27(\mathrm{~d}, J=5.6 \mathrm{~Hz}, 1 \mathrm{H}), 4.66(\mathrm{dd}, J=10.1,2.6 \mathrm{~Hz}, 1 \mathrm{H}), 4.43-$ $4.50(\mathrm{~m}, 1 \mathrm{H}), 4.41(\mathrm{~d}, J=10.1 \mathrm{~Hz}, 1 \mathrm{H}), 4.10(\mathrm{dd}, J=10.3,5.6 \mathrm{~Hz}, 1 \mathrm{H}), 3.85-$ $3.90(\mathrm{~m}, 1 \mathrm{H}), 3.55(\mathrm{dd}, J=10.3,3.3 \mathrm{~Hz}, 1 \mathrm{H}), 3.12-3.19(\mathrm{~m}, 1 \mathrm{H}), 2.57-2.67(\mathrm{~m}$, $1 \mathrm{H}), 1.99(\mathrm{~s}, 3 \mathrm{H}), 1.92-1.97(\mathrm{~m}, 1 \mathrm{H}), 1.65-1.74(\mathrm{~m}, 1 \mathrm{H}), 1.56(\mathrm{~d}, J=6.8 \mathrm{~Hz}$, $3 \mathrm{H}), 1.19-1.42(\mathrm{~m}, 5 \mathrm{H}), 0.99-1.12(\mathrm{~m}, 2 \mathrm{H}), 0.90(\mathrm{t}, J=7.2 \mathrm{~Hz}, 3 \mathrm{H})$; MS (FAB) $\mathrm{m} / \mathrm{z} 646(\mathrm{M}+\mathrm{H})^{+}$; HRMS (ESI) $\mathrm{m} / \mathrm{z}$ calcd for $\mathrm{C}_{26} \mathrm{H}_{37} \mathrm{FN}_{5} \mathrm{O}_{7} \mathrm{~S}_{3} 646.1834$, found $646.1836(\mathrm{M}+\mathrm{H})^{+}$.

Methyl (7S)-7-deoxy-7-[5-(4-fluoro-2-nitrophenyl)-1,3,4-thiadiazol2-yl-thio $]-6-N-\left[\left(2^{\prime} S, 4^{\prime} R\right)-1^{\prime}-N\right.$-methyl-4' -(n-propyl)piperidine-2'carbonyl]- $\alpha$-thiolincosaminide (8e)

The title compound was synthesized from $7 \mathrm{e}(55 \mathrm{mg}, 0.086 \mathrm{mmol})$ as a light yellow solid in $37 \%$ yield by the similar procedure to $8 \mathrm{~d}$. $[\alpha]_{\mathrm{D}}{ }^{26}+88^{\circ}(c 0.17$, $\left.\mathrm{CH}_{3} \mathrm{OH}\right) ;{ }^{1} \mathrm{H}$ NMR $\left(400 \mathrm{MHz}, \mathrm{CD}_{3} \mathrm{OD}\right) \delta 7.99(\mathrm{dd}, J=5.2 \mathrm{~Hz}, 1 \mathrm{H}), 7.85$ $(\mathrm{dd}, J=8.9,5.2 \mathrm{~Hz}, 1 \mathrm{H}), 7.61-7.67(\mathrm{~m}, 1 \mathrm{H}), 5.28(\mathrm{~d}, J=5.6 \mathrm{~Hz}, 1 \mathrm{H}), 4.69$ (dd, $J=10.2,2.4 \mathrm{~Hz}, 1 \mathrm{H}), 4.45-4.52(\mathrm{~m}, 1 \mathrm{H}), 4.43(\mathrm{~d}, J=10.2 \mathrm{~Hz}, 1 \mathrm{H}), 4.12$ (dd, $J=10.2,5.7 \mathrm{~Hz}, 1 \mathrm{H}), 3.84-3.86(\mathrm{~m}, 1 \mathrm{H}), 3.57(\mathrm{dd}, J=10.2,3.2 \mathrm{~Hz}, 1 \mathrm{H})$, 2.92-3.00 (m, 1H), 2.57-2.65 (m, 1H), $2.25(\mathrm{~s}, 3 \mathrm{H}), 2.10-2.18(\mathrm{~m}, 1 \mathrm{H}), 2.00(\mathrm{~s}$, $3 \mathrm{H}), 1.83-1.90(\mathrm{~m}, 1 \mathrm{H}), 1.68-1.74(\mathrm{~m}, 1 \mathrm{H}), 1.57(\mathrm{~d}, J=7.6 \mathrm{~Hz}, 3 \mathrm{H}), 1.20-1.40$ (m, 7H), 0.86-0.92 (m, 3H); MS (FAB) $\mathrm{m} / z 660(\mathrm{M}+\mathrm{H})^{+}$; HRMS (ESI) $\mathrm{m} / z$ calcd for $\mathrm{C}_{27} \mathrm{H}_{39} \mathrm{~N}_{5} \mathrm{O}_{7} \mathrm{~S}_{3} 660.1990$, found $660.1995(\mathrm{M}+\mathrm{H})^{+}$.

\section{Methyl (7S)-6- $N$-[(2'S, $\left.4^{\prime} R\right)-4^{\prime}$-(n-butyl)piperidine-2'-carbonyl $]-7-$ deoxy-7-[5-(4-fluoro-2-nitrophenyl)-1,3,4-thiadiazol-2-yl-thio]- $\alpha$ - thiolincosaminide $(7 \mathrm{f})$ \\ Reaction of $6 \mathbf{c}(500 \mathrm{mg}, 0.678 \mathrm{mmol})$ with 5-(4-fluoro-2-nitrophenyl)-1,3,4- thiadiazole-2-thiol (224 mg, $0.882 \mathrm{mmol}$ ) afforded $7 \mathrm{f}$ as a light yellow solid in $30 \%$ yield by the similar procedure to $7 \mathbf{a}$. $[\alpha]_{\mathrm{D}}{ }^{26}+100^{\circ}\left(c 0.27, \mathrm{CH}_{3} \mathrm{OH}\right) ;{ }^{1} \mathrm{H}$ NMR $\left(400 \mathrm{MHz}, \mathrm{CD}_{3} \mathrm{OD}\right) \delta 7.98(\mathrm{dd}, J=8.2,2,6 \mathrm{~Hz}, 1 \mathrm{H}), 7.85$ (dd, $J=8.6$, $5.2 \mathrm{~Hz}, 1 \mathrm{H}), 7.60-7.68(\mathrm{~m}, 1 \mathrm{H}), 5.28(\mathrm{~d}, J=5.6 \mathrm{~Hz}, 1 \mathrm{H}), 4.67(\mathrm{dd}, J=10.2$, $2.4 \mathrm{~Hz}, 1 \mathrm{H}), 4.43-4.51(\mathrm{~m}, 1 \mathrm{H}), 4.41(\mathrm{~d}, J=10.2 \mathrm{~Hz}, 1 \mathrm{H}), 4.10(\mathrm{dd}, J=10.2$, $5.6 \mathrm{~Hz}, 1 \mathrm{H}), 3.87-3.91(\mathrm{~m}, 1 \mathrm{H}), 3.56(\mathrm{dd}, J=10.2,3.2 \mathrm{~Hz}, 1 \mathrm{H}), 3.32-3.36(\mathrm{~m}$, $1 \mathrm{H}), 3.14-3.21(\mathrm{~m}, 1 \mathrm{H}), 2.61-2.71(\mathrm{~m}, 1 \mathrm{H}), 2.00-2.04(\mathrm{~m}, 1 \mathrm{H}), 1.99(\mathrm{~s}, 3 \mathrm{H})$, $1.68-1.75(\mathrm{~m}, 1 \mathrm{H}), 1.56(\mathrm{~d}, J=7.1 \mathrm{~Hz}, 3 \mathrm{H}), 1.23-1.34(\mathrm{~m}, 6 \mathrm{H}), 0.99-1.14(\mathrm{~m}$, $2 \mathrm{H}), 0.86-0.91(\mathrm{~m}, 3 \mathrm{H})$; MS (FAB) $\mathrm{m} / z 660(\mathrm{M}+\mathrm{H})^{+}$; HRMS (ESI) $\mathrm{m} / z$ calcd for $\mathrm{C}_{27} \mathrm{H}_{39} \mathrm{FN}_{5} \mathrm{O}_{7} \mathrm{~S}_{3} 660.1990$, found $660.1994(\mathrm{M}+\mathrm{H})^{+}$.}

\footnotetext{
Methyl (7S)-6-N-[(2'S, $\left.4^{\prime} R\right)-4^{\prime}$ - (n-butyl)-1'- $N$-methylpiperidine-2'carbonyl]-7-deoxy-7-[5-(4-fluoro-2-nitrophenyl)-1,3,4-thiadiazol-2yl-thio]- $\alpha$-thiolincosaminide (8f)

The title compound was synthesized from $7 \mathrm{f}(72 \mathrm{mg}, 0.11 \mathrm{mmol})$ as a light yellow solid in $85 \%$ yield by the similar procedure to $8 d$. $[\alpha]_{\mathrm{D}}{ }^{26}+94^{\circ}(c 0.22$, $\left.\mathrm{CH}_{3} \mathrm{OH}\right) ;{ }^{1} \mathrm{H}$ NMR $\left(400 \mathrm{MHz}, \mathrm{CD}_{3} \mathrm{OD}\right) \delta 7.98(\mathrm{dd}, J=8.2,2,6 \mathrm{~Hz}, 1 \mathrm{H}), 7.85$ $(\mathrm{dd}, J=8.6,5.2 \mathrm{~Hz}, 1 \mathrm{H}), 7.60-7.68(\mathrm{~m}, 1 \mathrm{H}), 5.28(\mathrm{~d}, J=5.6 \mathrm{~Hz}, 1 \mathrm{H}), 4.70(\mathrm{dd}$, $J=10.1,2.7 \mathrm{~Hz}, 1 \mathrm{H}), 4.45-4.53(\mathrm{~m}, 1 \mathrm{H}), 4.43(\mathrm{~d}, J=10.1 \mathrm{~Hz}, 1 \mathrm{H}), 4.12(\mathrm{dd}$, $J=10.2,5.6 \mathrm{~Hz}, 1 \mathrm{H}), 3.82-3.87(\mathrm{~m}, 1 \mathrm{H}), 3.57$ (dd, $J=10.2,3.3 \mathrm{~Hz}, 1 \mathrm{H}), 2.93-$ $3.01(\mathrm{~m}, 1 \mathrm{H}), 2.62-2.68(\mathrm{~m}, 1 \mathrm{H}), 2.27(\mathrm{~s}, 3 \mathrm{H}), 2.09-2.18(\mathrm{~m}, 1 \mathrm{H}), 2.00(\mathrm{~s}, 3 \mathrm{H})$,
}

$1.83-1.92(\mathrm{~m}, 1 \mathrm{H}), 1.67-1.76(\mathrm{~m}, 1 \mathrm{H}), 1.57(\mathrm{~d}, J=7.1 \mathrm{~Hz}, 3 \mathrm{H}), 1.21-1.42(\mathrm{~m}$, 9H), 0.85-0.93 (m, 3H); MS (FAB) $\mathrm{m} / z 674(\mathrm{M}+\mathrm{H})^{+}$; HRMS (ESI) $\mathrm{m} / z$ calcd for $\mathrm{C}_{28} \mathrm{H}_{41} \mathrm{FN}_{5} \mathrm{O}_{7} \mathrm{~S}_{3}$ 674.2147, found $674.2160(\mathrm{M}+\mathrm{H})^{+}$.

Methyl (7S)-7-deoxy-7-[5-(5-methylamino-2-nitrophenyl)-1,3,4thiadiazol-2-yl-thio $]-6-N-\left[\left(2^{\prime} S, 4^{\prime} R\right)-4^{\prime}-(n\right.$-propyl)piperidine-2' carbonyl]- $\alpha$-thiolincosaminide (7g)

Reaction of $\mathbf{6 b}$ (200 mg, $0.277 \mathrm{mmol}$ ) with 5-(5-methylamino-2-nitrophenyl)1,3,4-thiadiazole-2-thiol $(96.6 \mathrm{mg}, 0.360 \mathrm{mmol})$ afforded $7 \mathbf{g}$ as a yellow solid in $26 \%$ yield by the similar procedure to $7 \mathrm{a} .[\alpha]_{\mathrm{D}}{ }^{24}+91^{\circ}\left(\mathrm{c} 0.41, \mathrm{CH}_{3} \mathrm{OH}\right) ;{ }^{1} \mathrm{H}$ NMR $\left(300 \mathrm{MHz}, \mathrm{CDCl}_{3}\right) \delta 8.16(\mathrm{~d}, J=8.7 \mathrm{~Hz}, 1 \mathrm{H}), 6.62-6.72(\mathrm{~m}, 2 \mathrm{H}), 5.33$ (d, $J=5.7 \mathrm{~Hz}, 1 \mathrm{H}), 4.46-4.53(\mathrm{~m}, 1 \mathrm{H}), 4.31(\mathrm{~d}, J=9.9 \mathrm{~Hz}, 1 \mathrm{H}), 4.11-4.25(\mathrm{~m}$, $2 \mathrm{H}), 3.87-3.91(\mathrm{~m}, 1 \mathrm{H}), 3.56-3.68(\mathrm{~m}, 1 \mathrm{H}), 3.37-3.46(\mathrm{~m}, 1 \mathrm{H}), 3.16-3.24(\mathrm{~m}$, $1 \mathrm{H}), 2.91(\mathrm{~s}, 3 \mathrm{H}), 2.68-2.90(\mathrm{~m}, 2 \mathrm{H}), 2.61-2.68(\mathrm{~m}, 1 \mathrm{H}), 2.19(\mathrm{~s}, 3 \mathrm{H}), 2.00-$ $2.09(\mathrm{~m}, 1 \mathrm{H}), 1.64-1.72(\mathrm{~m}, 1 \mathrm{H}), 1.51(\mathrm{~d}, J=6.9 \mathrm{~Hz}, 3 \mathrm{H}), 1.16-1.36(\mathrm{~m}, 4 \mathrm{H})$, 0.98-1.12 (m, 2H), 0.79-0.89 (m, 3H); MS (FAB) $\mathrm{m} / z 657(\mathrm{M}+\mathrm{H})^{+}$; HRMS (ESI) $\mathrm{m} / z$ calcd for $\mathrm{C}_{27} \mathrm{H}_{41} \mathrm{~N}_{6} \mathrm{O}_{7} \mathrm{~S}_{3} 657.2193$, found $657.2193(\mathrm{M}+\mathrm{H})^{+}$.

Methyl (7S)-7-deoxy-7-[5-(5-methoxy-2-nitrophenyl)-1,3,4thiadiazol-2-yl-thio $]-6-N-\left[\left(2^{\prime} S, 4^{\prime} R\right)-4^{\prime}\right.$-(n-propyl)piperidine-2'carbonyl]- $\alpha$-thiolincosaminide (7h)

Reaction of 6b (200 mg, 0.277 mmol) with 5-(5-methoxy-2-nitrophenyl)-1,3,4thiadiazole-2-thiol $(97.0 \mathrm{mg}, 0.360 \mathrm{mmol}$ ) afforded $7 \mathrm{~h}$ as a light yellow solid in $24 \%$ yield by the similar procedure to $7 \mathrm{a} .[\alpha]_{\mathrm{D}}{ }^{24}+79^{\circ}\left(c 0.12, \mathrm{CH}_{3} \mathrm{OH}\right) ;{ }^{1} \mathrm{H}$ NMR (300 MHz, $\left.\mathrm{CDCl}_{3}\right) \delta 8.11-8.20(\mathrm{~m}, 1 \mathrm{H}), 7.07-7.16(\mathrm{~m}, 2 \mathrm{H}), 6.62-6.72$ $(\mathrm{m}, 2 \mathrm{H}), 5.36(\mathrm{~d}, J=5.7 \mathrm{~Hz}, 1 \mathrm{H}), 4.47-4.53(\mathrm{~m}, 1 \mathrm{H}), 4.09-4.35(\mathrm{~m}, 3 \mathrm{H}), 3.94$ (s, 3H), 3.77-3.89 (m, 1H), 3.55-3.70 (m, 1H), 3.36-3.51 (m, 1H), 3.16-3.29 $(\mathrm{m}, 1 \mathrm{H}), 2.65-2.79(\mathrm{~m}, 2 \mathrm{H}), 2.15(\mathrm{~s}, 3 \mathrm{H}), 1.98-2.09(\mathrm{~m}, 1 \mathrm{H}), 1.64-1.73(\mathrm{~m}$, $1 \mathrm{H}), 1.52(\mathrm{~d}, J=6.9 \mathrm{~Hz}, 3 \mathrm{H}), 1.17-1.36(\mathrm{~m}, 4 \mathrm{H}), 0.98-1.13(\mathrm{~m}, 2 \mathrm{H}), 0.77-0.89$ $(\mathrm{m}, 3 \mathrm{H})$; $\mathrm{MS}$ (FAB) $\mathrm{m} / \mathrm{z} 658(\mathrm{M}+\mathrm{H})^{+}$; HRMS (ESI) $\mathrm{m} / \mathrm{z}$ calcd for $\mathrm{C}_{27} \mathrm{H}_{40} \mathrm{~N}_{5} \mathrm{O}_{8} \mathrm{~S}_{3}$ 658.2034, found $658.2038(\mathrm{M}+\mathrm{H})^{+}$.

\section{Methyl (7S)-7-deoxy-6- $N$ - $\left[\left(2^{\prime} S, 4^{\prime} R\right)-4^{\prime}\right.$-ethylpiperidine-2'-} carbonyl]-7-[5-(4,5-dimethoxy-2-nitrophenyl)-1,3,4-thiadiazol-2-ylthio]- $\alpha$-thiolincosaminide (7i)

Reaction of $6 \mathrm{a}$ (158 mg, $0.223 \mathrm{mmol})$ with 5-(4,5-dimethoxy-2-nitrophenyl)1,3,4-thiadiazole-2-thiol $(80.0 \mathrm{mg}, 0.267 \mathrm{mmol})$ afforded $7 \mathbf{i}$ as a light yellow solid in $11 \%$ yield by the similar procedure to $7 \mathrm{a}$. $[\alpha]_{\mathrm{D}}{ }^{25}+89^{\circ}(c 0.46$, $\left.\mathrm{CH}_{3} \mathrm{OH}\right) ;{ }^{1} \mathrm{H}$ NMR $\left(400 \mathrm{MHz}, \mathrm{CD}_{3} \mathrm{OD}\right) \delta 7.75(\mathrm{~s}, 1 \mathrm{H}), 7.21(\mathrm{~s}, 1 \mathrm{H}), 5.28(\mathrm{~d}$, $J=5.6 \mathrm{~Hz}, 1 \mathrm{H}), 4.67(\mathrm{dd}, J=10.0,2.4 \mathrm{~Hz}, 1 \mathrm{H}), 4.40-4.48(\mathrm{~m}, 2 \mathrm{H}), 4.10(\mathrm{dd}$, $J=10.3,5.6 \mathrm{~Hz}, 1 \mathrm{H}), 3.98(\mathrm{~s}, 3 \mathrm{H}), 3.96(\mathrm{~s}, 3 \mathrm{H}), 3.88-3.91(\mathrm{~m}, 1 \mathrm{H}), 3.56(\mathrm{dd}$, $J=10.3,3.4 \mathrm{~Hz}, 1 \mathrm{H}), 3.14-3.20(\mathrm{~m}, 1 \mathrm{H}), 2.64(\mathrm{td}, J=12.9,2.7 \mathrm{~Hz}, 1 \mathrm{H}), 2.01(\mathrm{~s}$, $3 \mathrm{H}), 1.98$ (br s, $1 \mathrm{H}), 1.69-1.75(\mathrm{~m}, 1 \mathrm{H}), 1.55$ (d, $J=6.8 \mathrm{~Hz}, 3 \mathrm{H}), 1.39-1.49(\mathrm{~m}$, $1 \mathrm{H}), 1.24-1.34(\mathrm{~m}, 2 \mathrm{H}), 1.00-1.12(\mathrm{~m}, 2 \mathrm{H}), 0.92(\mathrm{t}, J=7.3 \mathrm{~Hz}, 3 \mathrm{H})$; MS (FAB) $m / z 674(\mathrm{M}+\mathrm{H})^{+}$; HRMS (ESI) $\mathrm{m} / z$ calcd for $\mathrm{C}_{27} \mathrm{H}_{40} \mathrm{~N}_{5} \mathrm{O}_{9} \mathrm{~S}_{3} 674.1983$, found $674.1988(\mathrm{M}+\mathrm{H})^{+}$.

Methyl (7S)-7-deoxy-7-[5-(4,5-dimethoxy-2-nitrophenyl)-1,3,4thiadiazol-2-yl-thio]-6- $N$-[(2'S, $\left.4^{\prime} R\right)-4^{\prime}$ - (n-propyl)piperidine-2' carbonyl]- $\alpha$-thiolincosaminide (7j)

Reaction of $\mathbf{6 b}$ ( $200 \mathrm{mg}, 0.277 \mathrm{mmol}$ ) with 5-(4,5-dimethoxy-2-nitrophenyl)1,3,4-thiadiazole-2-thiol $(99.4 \mathrm{mg}, 0.332 \mathrm{mmol}$ ) afforded $7 \mathbf{j}$ as a light yellow solid in $10 \%$ yield by the similar procedure to $7 \mathrm{a}$. $[\alpha]_{\mathrm{D}}{ }^{26}+97^{\circ}(c 0.30$, $\left.\mathrm{CH}_{3} \mathrm{OH}\right) ;{ }^{1} \mathrm{H}$ NMR $\left(400 \mathrm{MHz}, \mathrm{CD}_{3} \mathrm{OD}\right) \delta 7.77(\mathrm{~s}, 1 \mathrm{H}), 7.22(\mathrm{~s}, 1 \mathrm{H}), 5.28(\mathrm{~d}$, $J=5.6 \mathrm{~Hz}, 1 \mathrm{H}), 4.67(\mathrm{dd}, J=10.2,2.4 \mathrm{~Hz}, 1 \mathrm{H}), 4.39-4.48(\mathrm{~m}, 2 \mathrm{H}), 4.10(\mathrm{dd}$, $J=10.2,5.6 \mathrm{~Hz}, 1 \mathrm{H}), 3.99(\mathrm{~s}, 3 \mathrm{H}), 3.96(\mathrm{~s}, 3 \mathrm{H}), 3.87-3.90(\mathrm{~m}, 1 \mathrm{H}), 3.56(\mathrm{dd}$, $J=10.2,3.0 \mathrm{~Hz}, 1 \mathrm{H}), 3.32-3.38(\mathrm{~m}, 1 \mathrm{H}), 3.15-3.20(\mathrm{~m}, 1 \mathrm{H}), 2.63-2.71(\mathrm{~m}$, $1 \mathrm{H}), 2.02(\mathrm{~s}, 3 \mathrm{H}), 1.97-2.01(\mathrm{~m}, 1 \mathrm{H}), 1.68-1.75(\mathrm{~m}, 1 \mathrm{H}), 1.55(\mathrm{~d}, J=7.1 \mathrm{~Hz}$, $3 \mathrm{H}), 1.31-1.40(\mathrm{~m}, 2 \mathrm{H}), 1.20-1.28(\mathrm{~m}, 2 \mathrm{H}), 1.02-1.15(\mathrm{~m}, 3 \mathrm{H}), 0.90(\mathrm{t}$, $J=7.2 \mathrm{~Hz}, 3 \mathrm{H}$ ); MS (FAB) $\mathrm{m} / z 688(\mathrm{M}+\mathrm{H})^{+}$; HRMS (ESI) $\mathrm{m} / z$ calcd for $\mathrm{C}_{28} \mathrm{H}_{42} \mathrm{~N}_{5} \mathrm{O}_{9} \mathrm{~S}_{3}$ 688.2139, found $688.2153(\mathrm{M}+\mathrm{H})^{+}$. 
Methyl (7S)-6- $N-\left[\left(2^{\prime} S, 4^{\prime} R\right)-4^{\prime}-(n\right.$-butyl)piperidine-2' -carbonyl $]-7-$ deoxy-7-[5-(4,5-dimethoxy-2-nitrophenyl)-1,3,4-thiadiazol-2-ylthio]- $\alpha$-thiolincosaminide (7k)

Reaction of $\mathbf{6 c}$ (200 mg, $0.271 \mathrm{mmol})$ with 5-(4,5-dimethoxy-2-nitrophenyl)1,3,4-thiadiazole-2-thiol (106 $\mathrm{mg}, 0.353 \mathrm{mmol}$ ) afforded $7 \mathbf{k}$ as a light yellow solid in $19 \%$ yield by the similar procedure to $7 \mathbf{a}$. $[\alpha]_{\mathrm{D}}{ }^{26}+96^{\circ}(c) 0.49$, $\left.\mathrm{CH}_{3} \mathrm{OH}\right) ;{ }^{1} \mathrm{H}$ NMR $\left(400 \mathrm{MHz}, \mathrm{CD}_{3} \mathrm{OD}\right) \delta 7.75(\mathrm{~s}, 1 \mathrm{H}), 7.21(\mathrm{~s}, 1 \mathrm{H}), 5.28(\mathrm{~d}$, $J=5.7 \mathrm{~Hz}, 1 \mathrm{H}), 4.63-4.69(\mathrm{~m}, 1 \mathrm{H}), 4.38-4.47(\mathrm{~m}, 2 \mathrm{H}), 4.10(\mathrm{dd}, J=10.1$, $5.7 \mathrm{~Hz}, 1 \mathrm{H}), 3.98(\mathrm{~s}, 3 \mathrm{H}), 3.96(\mathrm{~s}, 3 \mathrm{H}), 3.87-3.90(\mathrm{~m}, 1 \mathrm{H}), 3.54-3.58(\mathrm{~m}, 1 \mathrm{H})$, $3.27-3.29(\mathrm{~m}, 1 \mathrm{H}), 3.12-3.18(\mathrm{~m}, 1 \mathrm{H}), 2.58-2.67(\mathrm{~m}, 1 \mathrm{H}), 2.01(\mathrm{~s}, 3 \mathrm{H}), 1.92-$ $2.00(\mathrm{~m}, 1 \mathrm{H}), 1.65-1.74(\mathrm{~m}, 1 \mathrm{H}), 1.55(\mathrm{~d}, J=6.8 \mathrm{~Hz}, 3 \mathrm{H}), 1.46-1.52(\mathrm{~m}, 1 \mathrm{H})$, $1.20-1.34$ (m, 6H), 0.99-1.11 (m, 2H), 0.86-0.93 (m, 3H); MS (FAB) $m / z 702$ $(\mathrm{M}+\mathrm{H})^{+}$; HRMS (ESI) $\mathrm{m} / z$ calcd for $\mathrm{C}_{29} \mathrm{H}_{44} \mathrm{~N}_{5} \mathrm{O}_{9} \mathrm{~S}_{3} 702.2296$, found 702.2294 $(\mathrm{M}+\mathrm{H})^{+}$.

\section{Methyl 7-deoxy-7-methyl-6- $N$ - $\left[\left(2^{\prime} S, 4^{\prime} R\right)-4^{\prime}\right.$-(n-propyl)piperidine- $2^{\prime}$-carbonyl]- $\alpha$-thiolincosaminide (VIC-105555) and methyl 7-} deoxy-7-methyl-6- $N$ - $\left[\left(2^{\prime} R, 4^{\prime} S\right)-4^{\prime}\right.$-(n-propyl)piperidine-2'carbonyl]- $\alpha$-thiolincosaminide (10)

To a solution of compound 9 (1.36 g, $3.41 \mathrm{mmol})$ in $\mathrm{MeOH}-\mathrm{H}_{2} \mathrm{O}(5: 2,100 \mathrm{ml})$ were added conc. hydrochloric acid $(410 \mu \mathrm{l}, 4.90 \mathrm{mmol})$, platinum (IV) oxide $(1.16 \mathrm{~g}, 5.12 \mathrm{mmom})$ and stirred under a hydrogen pressure of $3.9 \mathrm{MPa}$ at room temperature for $24 \mathrm{~h}$. The mixture was filtered and concentrated under reduced pressure. The resulting residue was added saturated aqueous $\mathrm{NaHCO}_{3}$ and extracted with ethyl acetate. The organic phase was dried over $\mathrm{Na}_{2} \mathrm{SO}_{4}$, filtered and concentrated under reduced pressure. The resulting residue was purified by silica gel column chromatography $\left(\mathrm{CHCl}_{3} / \mathrm{MeOH} / 28 \%\right.$ aq $\mathrm{NH}_{4} \mathrm{OH}=95 / 5 / 0.5$ to $85 / 15 / 1.5$ ), to afford the title compounds as colorless solids (VIC-105555; more polar, $630 \mathrm{mg}$, 46\%: 10; less polar, $653 \mathrm{mg}, 47 \%$ ). VIC-105555: $[\alpha]_{\mathrm{D}}{ }^{26}+170^{\circ}\left(c \mathrm{c} 0.91, \mathrm{CH}_{3} \mathrm{OH}\right) ;{ }^{1} \mathrm{H}$ NMR $\left(400 \mathrm{MHz}, \mathrm{CD}_{3} \mathrm{OD}\right) \delta$ $5.24(\mathrm{~d}, J=5.6 \mathrm{~Hz}, 1 \mathrm{H}), 4.16(\mathrm{~d}, J=10.0,3.1 \mathrm{~Hz}, 1 \mathrm{H}), 4.08(\mathrm{dd}, J=10.3$, $5.6 \mathrm{~Hz}, 1 \mathrm{H}), 4.04(\mathrm{~d}, J=10.0 \mathrm{~Hz}, 1 \mathrm{H}), 3.79-3.81(\mathrm{~m}, 1 \mathrm{H}), 3.51(\mathrm{dd}, J=10.3$, $3.2 \mathrm{~Hz}, 1 \mathrm{H}), 3.24-3.29(\mathrm{~m}, 1 \mathrm{H}), 3.10-3.16(\mathrm{~m}, 1 \mathrm{H}), 2.62(\mathrm{td}, J=12.8,2.8 \mathrm{~Hz}$, $1 \mathrm{H}), 2.12-2.20(\mathrm{~m}, 1 \mathrm{H}), 2.11(\mathrm{~s}, 3 \mathrm{H}), 1.89-1.96(\mathrm{~m}, 1 \mathrm{H}), 1.66-1.73(\mathrm{~m}, 1 \mathrm{H})$, $1.46-1.57(\mathrm{~m}, 1 \mathrm{H}), 1.32-1.41(\mathrm{~m}, 2 \mathrm{H}), 1.21-1.28(\mathrm{~m}, 2 \mathrm{H}), 0.98-1.10(\mathrm{~m}, 2 \mathrm{H})$, 0.89-0.96 (m, 9H); MS (FAB) $\mathrm{m} / z 405(\mathrm{M}+\mathrm{H})^{+}$; HRMS (ESI) $\mathrm{m} / \mathrm{z}$ calcd for $\mathrm{C}_{19} \mathrm{H}_{37} \mathrm{~N}_{2} \mathrm{O}_{5} \mathrm{~S}$ 405.2418, found $405.2422(\mathrm{M}+\mathrm{H})^{+} .10:[\alpha]_{D}^{26}+200^{\circ}(c \quad 1.2$, $\left.\mathrm{CH}_{3} \mathrm{OH}\right) ;{ }^{1} \mathrm{H}$ NMR $\left(400 \mathrm{MHz}, \mathrm{CD}_{3} \mathrm{OD}\right) \delta 5.25(\mathrm{~d}, J=5.7 \mathrm{~Hz}, 1 \mathrm{H}), 4.14(\mathrm{dd}$, $J=9.9,3.6 \mathrm{~Hz}, 1 \mathrm{H}), 4.09(\mathrm{dd}, J=10.2,5.7 \mathrm{~Hz}, 1 \mathrm{H}), 4.06(\mathrm{~d}, J=9.9 \mathrm{~Hz}, 1 \mathrm{H})$, $3.76-3.79(\mathrm{~m}, 1 \mathrm{H}), 3.52(\mathrm{dd}, J=10.2,3.5 \mathrm{~Hz}, 1 \mathrm{H}), 3.24(\mathrm{dd}, J=11.6,2.8 \mathrm{~Hz}$ $1 \mathrm{H}), 3.08-3.14(\mathrm{~m}, 1 \mathrm{H}), 2.61(\mathrm{td}, J=12.7,2.7 \mathrm{~Hz}, 1 \mathrm{H}), 2.12-2.19(\mathrm{~m}, 1 \mathrm{H}), 2.11$ (s, 3H), 1.93-1.99 (m, 1H), 1.65-1.72 (m, 1H), 1.42-1.55 (m, 1H), 1.31-1.42 (m, 2H), 1.20-1.29 (m, 2H), 0.96-1.11 (m, 2H), 0.88-0.96 (m, 9H); MS (FAB) $m / z 405(\mathrm{M}+\mathrm{H})^{+}$; HRMS (ESI) $m / z$ calcd for $\mathrm{C}_{19} \mathrm{H}_{37} \mathrm{~N}_{2} \mathrm{O}_{5} \mathrm{~S} 405.2418$, found 404.2423 $(\mathrm{M}+\mathrm{H})^{+}$.

\section{In vitro antibacterial activity}

MIC was determined by the agar dilution method. Test strains were subjected to seed culture using sensitivity test broth (Nissui Pharmaceutical, Tokyo, Japan) cultured on blood agar plate for S. pneumoniae, S. pyogenes and $H$. influenzae. A $5 \mu \mathrm{l}$ portion of cell suspension of the test strains having about $10^{6} \mathrm{CFU} \mathrm{ml}{ }^{-1}$ was inoculated into sensitivity disk agar (Nissui Pharmaceutical) supplemented with $5 \%$ horse blood and incubated at $37^{\circ} \mathrm{C}$ for $20 \mathrm{~h}$. Then, MIC was defined as the lowest drug concentration that prevented visible growth.

\section{CONFLICT OF INTEREST}

The authors declare no conflict of interest.

\section{ACKNOWLEDGEMENTS}

We thank Dr E Shitara, Mr. A Tamura and Dr T Okutomi for valuable scientific discussion. We are grateful to Professor Emeritus Dr M Konno for supervision through our in-house drug discovery program in lincomycin field. We are also grateful to Ms. T Miyara, Ms. S Miki, Ms. K Kaneda, Dr T Murata and Mr. S Sato for contribution toward analytical chemistry; Mr. Y Takayama for biological studies; and Ms. M Takagi for manuscript. We also thank Ms. M Ishii for direction in intellectual properties.

1 Morimoto, S., Takahashi, Y., Watanabe, Y. \& Ōmura, S. Chemical modification of erythromycins. I. Synthesis and antibacterial activity of 6-0-methylerythromycins A. J. Antibiot. 37, 187-189 (1984).

2 Slobodan, D. et al. Erythromycin series. Part 13. Synthesis and structure elucidation of 10-dihydro-10-deoxo-11-methyl-11-azaerythromycin A. J. Chem. Res. Synop. 1988, 152-153 (1988).

3 Ajito, K., Miura, T., Furuuchi, T. \& Tamura, A. Sixteen-membered macrolides: chemica modifications and future applications. Heterocycles 89, 281-352 (2014).

4 Sato, T. et al. In vitro antibacterial activity of modithromycin, a novel 6,11-bridged bicyclolide, against respiratory pathogens, including macrolide-resistant Grampositive cocci. Antimicrob. Agents Chemother. 55, 1588-1593 (2011).

5 Denis, A. et al. Synthesis and antibacterial activity of HMR 3647 a new ketolide highly potent against erythromycin-resistant and susceptible pathogens. Bioorg. Med. Chem. Lett. 9, 3075-3080 (1999).

6 Clay, K. D. et al. Severe hepatotoxicity of telithromycin: three case reports and literature review. Ann. Intern. Med. 144, 415-420 (2006).

7 Miura, T. et al. Novel azalides derived from sixteen-membered macrolides. I. Isolation of the mobile dialdehyde and its one-pot macrocyclization with an amine. J. Antibiot. 60, 407-435 (2007).

8 Miura, T. et al. Novel azalides derived from 16-membered macrolides. III. Azalides modified at the C-15 and 4" positions: improved antibacterial activities. Bioorg. Med. Chem. 18, 2735-2747 (2010).

9 Mason, D. J., Dietz, A. \& Deboer, C. Lincomycin, a new antibiotic I. Discovery and biological properties. Antimicrob. Agents Chemother. 1962, 554-559 (1962).

10 Birkenmeyer, R. D. \& Kagan, F. Lincomycin. XI. Synthesis and structure of clindamycin. A potent antibacterial agent. J. Med. Chem. 13, 616-619 (1970).

11 Weisblum, B. Erythromycin resistance by ribosome modification. Antimicrob. Agents Chemother. 39, 577-585 (1995).

12 Tsuzuki, K. et al. Motilides, macrolides with gastrointestinal motor stimulating activity. I. O-substituted and tertiary $\mathrm{N}$-substituted derivatives of 8,9-anhydroerythromycin $\mathrm{A}$ 6,9-hemiacetal. Chem. Pharm. Bull. 37, 2687-2700 (1989).

13 Shah, P. J. Vakil, N. \& Kabakov, A. Role of intravenous immune globulin in streptococcal toxic shock syndrome and Clostridium difficile infection. Am. J. Health Syst. Pharm. 72, 1013-1019 (2015).

14 Sztaricskai, F. et al. Semisynthetic modification of antibiotic lincomycin. J. Antibiot. 49, 941-943 (1996).

15 Goffic, L. F. Structure activity relationships in lincosamide and streptogramin antibiotics. J. Antimicrob. Chemother. 16(Suppl A), 13-21 (1985).

16 Umemura, E. et al. Synthesis of novel lincomycin derivatives and their in vitro antibacterial activities. J. Antibiot. 66, 195-198 (2013).

17 Wakiyama, Y. et al. Synthesis and structure-activity relationships of novel lincomycin derivatives. Part 1. Newly generated antibacterial activities against Gram-positive bacteria with erm gene by C-7 modification. J. Antibiot. 69, 368-380 (2016).

18 Wakiyama, Y. et al. Synthesis and structure-activity relationships of novel lincomycin derivatives. Part 2. Synthesis of 7(S)-7-deoxy-7-(4-morpholinocarbonylphenylthio)lincomycin and its 3-dimensional analysis with rRNA. J. Antibiot. 69, 428-439 (2016).

19 Wakiyama, Y. et al. Synthesis and structure-activity relationships of novel lincomycin derivatives part 3: discovery of the 4-(pyrimidin-5-yl)phenyl group in synthesis of 7(S)thiolincomycin analogs. J. Antibiot. 70, 52-64 (2017).

20 Kumura, K. et al. Synthesis and antibacterial activity of novel lincomycin derivatives. I. Enhancement of antibacterial activities by introduction of substituted azetidines. $J$. Antibiot. 69, 440-445 (2016).

21 Kumura, K. et al. Synthesis and antibacterial activity of novel lincomycin derivatives. II. Synthesis and antibacterial activity of novel lincomycin derivatives. II. Exploring (7S) -7(5-aryl-1,3,4-thiadiazol-2-yl-thio)-7-deoxylincomycin derivatives. J. Antibiot. 70, 655-663 (2017).

22 Kumura, K. et al. Synthesis and antibacterial activity of novel lincomycin derivatives. III. Optimization of a phenyl thiadiazole moiety. J. Antibiot. doi:10.1038/ja.2017.59 (2017).

23 Birkenmeyer, R. D., Kroll, S. J., Lewis, C., Stern, K. F. \& Zurenko, G. E. Synthesis and antimicrobial activity of clindamycin analogues: pirlimycin, a potent antibacterial agent. J. Med. Chem. 27, 216-223 (1984).

24 Lewis, J. G. et al. The lincomycin derivatives possessing antibacterial activity. WO/ 2004/016632 A2, 26 February (2004).

25 Lewis, J. G. et al. Novel Antimicrobial 7-Methyl Lincosamides: Pipecolamide Analogs. 43rd Interscience Conference on Antimicrobial Agents and Chemotherapy. Poster F-1389 (2004).

26 Lopez, S. L. et al. Characterization of the Spectrum of In Vitro Activity of VIC-105555, a New Lincosamide. 44th Interscience Conference on Antimicrobial Agents and Chemotherapy. Poster F-2038 (2004).

27 O'Dowd, H. et al. Novel antibacterial azetidine lincosamides. Bioorg. Med. Chem. Lett 18, 2645-2648 (2008).

28 Shuman, R. T., Ornstein, P. L., Paschal, J. W. \& Gesellchen, P. D. An improved synthesis of homoproline and derivatives. J. Org. Chem. 55, 738-741 (1990).

29 Schroeder, W., Bannister, B. \& Hoeksema, H. Lincomycin. III. The structure and stereochemistry of the carbohydrate moiety. J. Am. Chem. Soc. 89, 2448-2453 (1967).

30 Eldere, J. V. et al. Overview of antimicrobial options for Mycoplasma pneumoniae pneumonia: focus on macrolide resistance. Clin. Respir. J. 11, 419-429 (2017). 